\title{
Biomass and element pools of understory vegetation in the catchments of Čertovo Lake and Plešné Lake in the Bohemian Forest
}

\author{
Miroslav Svoboda ${ }^{1}$, Karel MatĚJKA ${ }^{2}$ \& Jiří KopÁČEK ${ }^{3}$ \\ ${ }^{1}$ Czech University of Agriculture in Prague, Faculty of Forestry and Environment, Kamýcká 129, CZ-16521 Praha 6 - \\ Suchdol, Czech Republic; e-mail: svobodam@fle.czu.cz \\ ${ }^{2}$ IDS, Na Komořsku 2175/2A,CZ-14300 Praha 4, Czech Republic; e-mail: ids@infodatasys.cz \\ ${ }^{3}$ Biology Centre, Academy of Sciences of the Czech Republic, Institute of Hydrobiology, Na Sádkách 7, CZ-37005 Ceské \\ Budějovice, Czech Republic; e-mail: jkopacek@hbu.cas.cz
}

\begin{abstract}
This paper presents data on species composition, biomass, and element pools (C, N, P, Ca, Mg, Na, K, Al, Fe, $\mathrm{Mn}$ ) of the understory vegetation of spruce forests in the catchments of lakes Čertovo jezero (CT) and Plešné jezero (PL) in the Bohemian Forest (Sumava, Czech Republic). Calamagrostis villosa was the most abundant species in the CT catchment, while Vaccinium myrtillus was the most abundant species in the PL catchment. The catchments weighted mean (CWM) of above-ground biomass of the understory vegetation was 288 and $723 \mathrm{~g} \mathrm{~m}^{-2}$ in the CT and PL catchments, respectively. The significant difference in the biomass between the catchments was caused by the much higher abundance of $V$. myrtillus in the PL catchment. The CWM of below-ground biomass of the fine roots was 491 and $483 \mathrm{~g} \mathrm{~m}^{-2}$ in the CT and PL catchments, respectively. The respective CWM element pools of biomass in the CT and PL catchments were: C (33 and 51

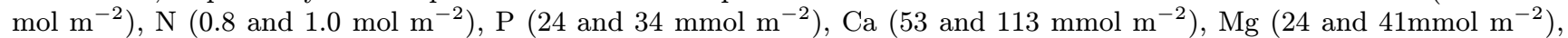
$\mathrm{Na}\left(3.7\right.$ and $\left.6.5 \mathrm{mmol} \mathrm{m}^{-2}\right), \mathrm{K}\left(83\right.$ and $\left.109 \mathrm{mmol} \mathrm{m}^{-2}\right), \mathrm{Al}\left(50\right.$ and $\left.42 \mathrm{mmol} \mathrm{m}^{-2}\right), \mathrm{Fe}\left(13.3\right.$ and $\left.7.3 \mathrm{mmol} \mathrm{m}^{-2}\right)$, and $\mathrm{Mn}$ $\left(4.2\right.$ and $\left.8.8 \mathrm{mmol} \mathrm{m}^{-2}\right)$.
\end{abstract}

Key words: Norway spruce forest, understory vegetation, Calamagrostis villosa, Vaccinium myrtillus.

\section{Introduction}

Forest research has always tended to focus on the trees, while much less attention has been paid to understory components such as dwarf shrubs, herbs, grass, ferns and mosses (NILSSON \& WARDLE, 2005). However, the importance of understory vegetation in forest ecosystems is probably comparable to that of the trees. The ecological importance of understory vegetation can be viewed at the vegetation and soil process scales. Understory vegetation can strongly influence tree seedling establishment and growth (GEORGE \& BAzZAZ, 1999) and thus the dynamics of the whole forest stand. Soil processes affect belowground processes, such as decomposition and build-up of soil nutrients (JONASSON \& SHAVER, 1999). Understory vegetation can also serve as an important pool of nutrients in forest ecosystems. For example, the annual aboveground production of understory vegetation was estimated to be between 25 and $32 \%$ of total aboveground biomass for a Norway spruce stand in boreal Fennoscandia (FInER et al., 2003). In the same stands, the annual uptake of $\mathrm{C}$ and $\mathrm{N}$ by understory vegetation represented as much as 22 and
$56 \%$ of the annual net uptake of $\mathrm{C}$ and $\mathrm{N}$ by trees, respectively (FINER et al., 2003). Similar values were reported for Scots pine dominated forests from boreal Fennoscandia (HelmisaARI, 1995). According to some recent studies, understory vegetation can also affect and modify nutrient flow in forest ecosystems (RoDENKIRCHEN, 1995; HUBER et al., 2004). It has been shown that grass understory vegetation can serve as an important sink of atmospheric nitrogen (HoLUB, 1999). Sward grass vegetation can also decrease soil acidity and the loss of base cations (FIALA et al., 2005). This suggests that some species of understory vegetation can partly eliminate negative processes associated with soil acidification and positively affect the reduction of nutrient losses from the soil (FIALA et al., 2005). Contradictory results were found by ŠANTRŮČKOVÁ et al. (2006), showing that vegetation cover of Calamagrostis villosa possibly contributed to high $\mathrm{N}$ flux from the litter in the spruce forest of the Bohemian Forest. On the whole catchment scale, $\mathrm{N}$ flux from the litter was similar to $\mathrm{N}$ input by atmospheric deposition. Based on these results, there is an obvious need for detailed studies on the role of understory vegetation 
within the process of element cycling on the catchment scale.

The aim of this paper is to evaluate differences in the character, biomass and element pools of the understory vegetation in the spruce forest of two Bohemian Forest catchments of lakes Plešné jezero (PL) and Čertovo jezero (CT). Catchments of both lakes have been exposed to high deposition of S and N compounds during the last six decades, but have been partly recovering from this acid stress since the late 1980s (MAJER et al., 2003). Long term ecosystem research focusing on the process of ecosystem acidification and biological recovery has been carried out in both catchments since 1990 (VRBA et al., 2003). Despite similar climatic and morphological conditions, there are significant differences in the $\mathrm{N}$ and $\mathrm{P}$ fluxes within the ecosystems, as well as in rates of their biological recovery (KopÁčEK et al., 2002c; MAJER et al., 2003). The role of the different bedrock and soils on these processes have been recently studied (KAŇA \& KopÁČEK, 2006; KopÁČEK et al., $2006 \mathrm{a}, \mathrm{b})$. However, the important part of the catchment ecosystem, the vegetation layer, was neglected until now, because of the lack of reliable data. This study presents the first analysis of the understory vegetation and related element pools for these ecosystems. Here we evaluate: (1) differences in the species composition and biomass of the understory vegetation and the associated pools of major nutrients (C, N, P, Ca, Mg, and $\mathrm{K}$ ) and ecologically important metals $(\mathrm{Al}, \mathrm{Fe}, \mathrm{Mn})$ in the catchments of the PL and CT lakes, (2) spatial variability of the studied characteristics (biomass and element pools) within the catchments, and (3) a comparison of the biomass and element pools in the catchments to other available data from Central European spruce forest ecosystems. A comparison of element pools associated with the understory vegetation to those in the soil and tree layers are given in SvobodA et al. (2006). The role of the understory vegetation in the cycling of terrestrial elements is evaluated by ŠANTRŮČKOVÁ et al. (2006).

\section{Study sites}

The research was carried out in the catchments of Plešné Lake (PL; $48^{\circ} 46^{\prime} 35^{\prime \prime} \mathrm{N}, 13^{\circ} 52^{\prime} 0^{\prime \prime}$ E; elevation of $1087-1378$ $\mathrm{m}$ a.s.l.; total forested area of $59.5 \mathrm{ha}$ ) and Certovo Lake $\left(\mathrm{CT} ; 49^{\circ} 9^{\prime} 55^{\prime \prime} \mathrm{N}, 13^{\circ} 11^{\prime} 50^{\prime \prime} \mathrm{E}\right.$; elevation of $1027-1343 \mathrm{~m}$ a.s.l.; total forested area of 81.2 ha) in the Bohemian Forest (Sumava, Böhmerwald). The PL catchment is nearly completely covered with forest ( $\sim 90 \%$ of the catchment). The forest stand is on average 160 years old and dominated (99\%) by Norway spruce (Picea abies), with minor contributions of mountain-ash (Sorbus aucuparia) and beech (Fagus sylvatica). Timber biomass ranges between 15 and $720 \mathrm{~m}^{3} \mathrm{ha}^{-1}$ (catchment average of $230 \mathrm{~m}^{3} \mathrm{ha}^{-1}$ ) according to the Stožec, 1995-2004, and Plešný, 1996-2005 forest management plans (I. VICENA - pers. commun.). Only few data are available in the literature on the history of landuse in the PL catchment, summarised by VESELY (1994).
Disturbances occasionally affecting the surroundings of the PL catchment (logging, pasturing, or fires) were probably negligible within the catchment during the last $\sim 250$ years (I. VICENA - pers. commun.). Details on forest development in the study area are given by JANKOVSKÁ (2006). The bedrock of the PL catchment is granite, soils are developed from till, rich in sand $(\sim 75 \%)$, and consist of $\sim 0.2$ $\mathrm{m}$ deep leptosol $(38 \%)$ and $\sim 0.45 \mathrm{~m}$ deep podsol $(29 \%)$ or dystric cambisol (27\%). The rest of the watershed is rocky; wetlands are negligible $(\sim 1 \%)$. Soil $\mathrm{pH}\left(\mathrm{CaCl}_{2}\right.$ extractable) is low, with minimum values of $2.5-3.1$ in A-horizons and maximum (3.2-4.4) in low mineral horizons. The mean effective cation exchange capacity of the soils is dominated by exchangeable $\mathrm{Al}(57 \%)$ and protons (28\%), while base saturation is $15 \%$ (KOPÁČEK et al., 2002a).

The Certovo Lake catchment is covered with $90-150$ year-old Norway spruce forest (Picea abies) of at least secondary origin, with sparse European beech (Fagus sylvat$i c a$ ). Timber biomass is (according to the Železná Ruda 2003 forest management plans; I. VICENA - pers. commun.) on average $287 \mathrm{~m}^{3} \mathrm{ha}^{-1}$. The land use history of the CT catchment is summarised by VESELY (1994), and suggests important timber harvesting and charcoal and potash production from the Middle Ages to the late $19^{\text {th }}$ century. The bedrock of the CT catchment is made up of mica-schist (muscovitic gneiss), quartzite, and small amounts of pegmatite (VESELY, 1994). The watershed is covered with $\sim 0.5$ $\mathrm{m}$ deep dystric cambisol (58\%), podsol (21\%), and shallow $(\sim 0.2 \mathrm{~m})$ leptosol $(17 \%)$; wetlands and bare rocks represent $\sim 3 \%$ and $1 \%$, respectively. Fine soil is sandy (48-81\%) with a low (1-4\%) content of clay. Soil $\mathrm{pH}\left(\mathrm{CaCl}_{2}\right.$ extractable $)$ is low, with minimum values of $2.5-3.3$ in A-horizons and maximum values of $3.6-4.5$ in mineral horizons. The mean effective cation exchange capacity of the soils is dominated by exchangeable $\mathrm{Al}(62 \%)$ and protons (29\%), while base saturation is $9 \%$ (KOPÁČEK et al., 2002b).

As determined from typological maps (using the Czech typological system; VIEWEGH et al., 2003), the CT catchment belongs to the spruce-beech vegetation zone ( $81 \%$ of forested area) and spruce vegetation zone (19\% of forested area). The PL catchment belongs to the spruce-beech vegetation zone $(12 \%)$ and spruce vegetation zone $(88 \%)$. The distribution and fractions of the groups of the forest types presented within the catchment are shown in Figs 1a and $1 \mathrm{~b}$.

\section{Material and methods}

Sampling and analysis of the understory vegetation The investigation of understory vegetation was carried out using the following steps: (1) Plant communities (using plant coenological relevés) were inspected and the boundaries between the distinguished plant communities surveyed. (2) All important types of plant microcoenoses within the plant communities (sensu MATĚJKA, 1992b), based on the dominant plant species, were determined by field reconnaissance. (3) Each type of microcoenose within each plant community was sampled to determine aboveground (AG) and belowground (BG) biomass. (4) The area of each plant community was calculated (total area of plant communities gave the total catchment area). (5) Total biomass and catchment weighted mean (CWM) biomass were calculated. (6) Selected elements were analyzed in dried biomass samples (or mixed samples). (7) Total pools of these elements and CWM 
pools were calculated using total species biomass and mean element concentration in above-ground and below-ground biomass.

Biomass of the understory vegetation was estimated in both catchments using a combination of the phytosociological survey and biomass sampling during July and August 2004. The forest site typology maps, available at the Regional Plan of Forest Development (prepared by The Forest Management Institute, Brandýs n. Labem), were used as the basis for further plant coenological surveys. According to these maps, the main sets of forest types were distinguished and their area analyzed in GIS. The sets of forest types characterize specific site conditions and therefore a certain composition of plant species (VIEWEGH et al., 2003). After that, a basic field survey analyzing the dominant microcoenoses and plant communities, and the variability in plant species composition within the plant communities, was carried out. In the next step, 35 and 23 plant coenological relevés distributed within the dominant plant communities were recorded in the $\mathrm{CT}$ and PL catchments, respectively. The phytosociological surveys were carried out using standard methods (e.g., MorAVEC et al., 1994). Plant nomenclature follows KUBÁT et al. (2002). Each relevé was a circle plot with area of about $200 \mathrm{~m}^{2}$. The relevés were placed randomly within the catchments and plant communities. The number of relevés placed in the individual plant communities was proportional to their area. Any distinct change in cover and composition of the plant species encountered during both the basic and phytosociological surveys was marked on the map.

Abundance of the individual plant species was used to distinguish between the plant species that were analyzed for element concentrations. Plant species were not analyzed if their mean abundance was less than $1 \%$ in the whole catchment. The following plant species had a mean abundance $>1 \%$ in both catchments: Athyrium distentifolium, Avenella flexuosa, Calamagrostis villosa, Luzula sylvatica, and Vaccinium myrtillus. These species created the main microcoenoses and plant communities, and the understory vegetation in both catchments was finely-structured according to these dominant species.

A $0.5 \times 0.5 \mathrm{~m}$ frame was used to sample (AG) biomass of the understory vegetation. The frames were randomly placed within both catchments to cover variability in site and stand conditions. The number of biomass samples for individual plant species depended on their relative abundance in each of the catchments. Biomass samples were assigned to microcoenose types and plant communities according to the dominant plant species. For each sample site, AG plant material was cut using a pair of scissors, put into a plastic bag and labelled. The AG biomass samples were brought to the laboratory and individual plant species separated. The AG biomass of $V$. myrtillus was separated into leaves, annual shoots, and woody stems. In this way, the annually produced biomass of $V$. myrtillus was estimated, and the production of AG biomass between the perennial plant species (V. myrtillus) and annual plant species (the other species in the catchments) were compared. The samples were dried at $105^{\circ} \mathrm{C}$ till their weight was stabilized.

A steel corer with a $6.5 \mathrm{~cm}$ diameter was used to sample BG biomass. Depth of the soil cores depended on local soil properties (e.g., content of bigger stones). The overall mean depth of the soil cores was about $15 \mathrm{~cm}$; i.e. soil cores contained the majority of the fine root biomass. After sampling, the material was withdrawn from the steel corer and put into a plastic bag. The BG biomass samples were cleaned in the laboratory using running water on a set of sieves $>0.25 \mathrm{~mm}$ in diameter. They were then divided into the following categories: non-woody fine roots, woody roots, and rhizomes. After that, the samples were dried at $105^{\circ} \mathrm{C}$ until their weight was stabilized.

The following sampling design was used for Athyrium distentifolium, which grew in large tussocks. In the area with a high abundance of this species, two rectangular plots (12 and $16 \mathrm{~m}^{2}$ ) were set only in the CT catchment. All tussocks of $A$. distentifolium in the grid plots were counted and their diameter measured. Then, the AG biomass of several tussocks over a range of diameters was sampled in both catchments. The BG biomass of $A$. distentifolium was sampled in the centre, middle and edge of average-sized tussocks.

All mass and chemical results further reported in this paper are given on a dry weight biomass basis.

\section{Chemical analysis of the biomass}

The dry biomass was analysed for total content of the following elements. Total $\mathrm{P}$ was determined from a $\mathrm{HNO}_{3}$ and $\mathrm{HClO}_{4}$ acid digest using the phosphomolybdate blue method (KOPÁČEK et al., 2001). Carbon (C) and nitrogen (N) were determined by a CN analyser (NC 2100, ThermoQuest, Italy). The total concentration of metals ( $\mathrm{Ca}, \mathrm{Mg}$, $\mathrm{Na}, \mathrm{K}, \mathrm{Al}, \mathrm{Fe}$, and $\mathrm{Mn}$ ) was analysed using a $\mathrm{H}_{2} \mathrm{SO}_{4}, \mathrm{HNO}_{3}$, and $\mathrm{HF}$ mixed acid digest $\left(200^{\circ} \mathrm{C}, 2 \mathrm{~h}\right)$ by flame atomic absorption spectrometry.

\section{Statistical analyses}

The phytosociological relevés were classified using TWINSPAN (HILL, 1979). The types of plant communities were distinguished according to TWINSPAN classification accounting $3^{\text {rd }}$ classification level. The main types of plant communities (vegetation groups) were determined based on the result of this procedure. The results of the phytosociological survey within the types of plant communities, the distribution of the groups of plant communities in the catchments, and the map notes made during the surveys were used in GIS to analyse and distinguish borders and areas of individual plant communities. The total area of the plant communities groups was later used to calculate the total biomass and CWM biomass of the understory vegetation in each catchment.

Dry weight values of AG biomass of analyzed plant species samples, except $A$. distentifolium, were used to calculate the mean AG biomass individual plant species, which was calculated using equation (1) (competition model of coexistence of the selected plant species) (MATĚJKA, 1992a):

$$
A f \cdot a^{-1}+C v \cdot c^{-1}+L s \cdot l^{-1}+V m \cdot v^{-1}=1,
$$

where $a, c, l, v$ are the values of the "carrying capacity" representing the maximum weight of the biomass $\left(\mathrm{g} \mathrm{m}^{-2}\right)$ of the species growing in a monocoenose, and $A f$ (A. flexuosa), Cv (C. villosa), Ls (L. sylvatica), Vm (V. myrtillus) are the mean dry weights of biomass $\left(\mathrm{g} \mathrm{m}^{-2}\right)$ of the species in the given sample. The least square method was used to calculate a regression model. The term carrying capacity is used here in a similar meaning as by ODUM (1959), giving the maximum value of species biomass achievable under optimal conditions. In our sense, it means without the presence of any other competing species. AG biomass values of 
A. distentifolium were calculated using a regression model, where the weight of AG biomass $(m ; \mathrm{g})$ is expressed as a function of tussock diameter $(D ; \mathrm{cm})$ :

$$
m=a \times D^{b},
$$

where $a$ and $b$ represent result of the regression solution.

The carrying capacity values for individual plant species (or mean biomass of $A$. distentifolium), in other words the biomass of $i$-th species per unit area $-B_{i}$, cover of $i$-th species in the $j$-th plant community type $-C_{i j}$, and the area of the $j$-th plant community type $-A_{j}$ (the sum of area of all plant communities gives the total catchment area), were used to calculate the CWM of AG biomass of the $i$-th species in both catchments:

$$
C W M_{i}=B_{i} \times \sum_{j} C_{i j} \times A_{j} / \sum_{j} A_{j}
$$

This catchment weighting generates a single value for each parameter, representing a hypothetical situation when all representatives of understory vegetation are uniformly distributed over the whole catchment. The total CWM AG biomass was calculated over all incorporated species.

The mean BG biomass was calculated for all types of microcoenoses. The final BG biomass means have therefore limited significance. The CWM of BG biomass was calculated as a function of mean BG biomass in the $i$-th type of microcoenose $-B_{i}$, relative representation of the $i$-th type of microcoenose in the $j$-th plant community type $-R_{i j}$, and the area of the $j$-th community type $-A_{j}$ (whole catchment area was divided into areas of plant community types):

$$
C W M=\sum_{i, j} B_{i} \times R_{i j} \times A_{i} / \sum_{j} A_{j}
$$

Total element pools were calculated as a function of the CWM and mean element concentrations of AG and BG biomass (according to individual plant species) for each of the catchments.

\section{Results}

\section{Plant coenological surveys}

Clear differences were found between the plant communities in the catchments of both lakes. C. villosa was the most abundant species in the CT catchment, while $V$. myrtillus was the most abundant species in the PL catchment (Tab. 1). There were 5 main types of understory vegetation plant communities in each of the catchments. Groups ${ }^{*} 000,{ }^{*} 001$, and ${ }^{*} 111$ were dominated by $A$. distentifolium and represented the association Athyrio alpestris-Piceetum Hartman ex Hartmann et Jahn, 1967 on wet sites. Other groups of plant communities with various shares of $C$. villosa and V. myrtillus belonged to the broad association Calamagrostio villosae-Piceetum Hartman in Hartmann et Jahn, 1967 (compare Husové et al., 2002). Types *010 and ${ }^{*} 011$ surrounding CT Lake were classified as the association Calamagrostio villosae-Fagetum Mikyška,
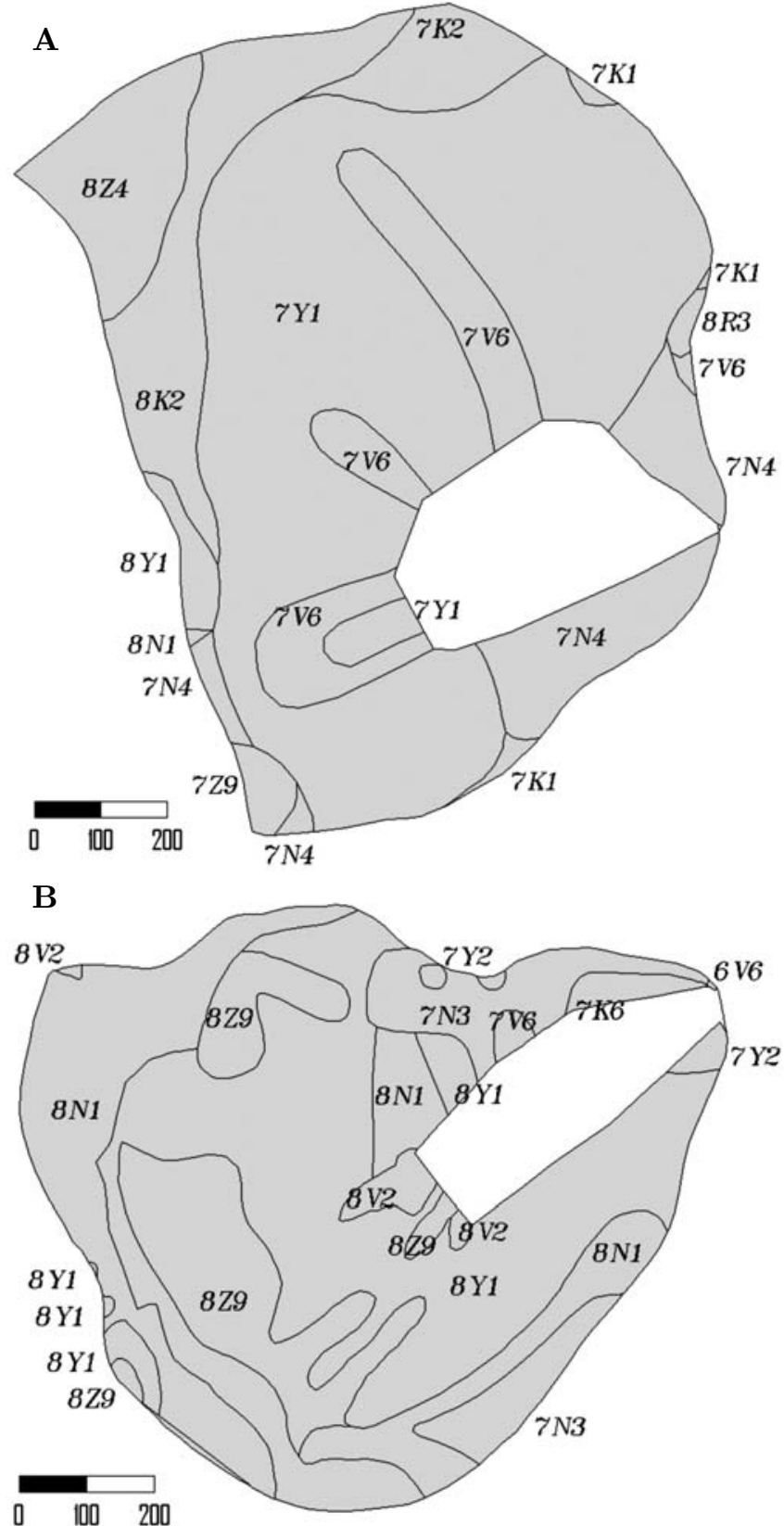

Fig. 1. A - Map of forest types in the catchments of Čertovo Lake. The share of the individual forest type group in the CT catchment was: $7 \mathrm{Y}-$ Fageto-Piceetum saxatilis $-57.4 \%, 7 \mathrm{~K}-$ FagetoPiceetum acidophilum - 4.4\%, 7V - Fageto-Piceetum acerosum humidum - 9.7\%, 8Z - Sorbeto-Piceetum (humilis) - 6.8\%, $7 \mathrm{~N}-$ Fageto-Piceetum lapidosum acidophilum $-8.9 \%, 8 \mathrm{~N}$ - Piceetum lapidosum acidophilum - 0.1\%, 8Y - Piceetum saxatile $-1.3 \%$, $7 \mathrm{Z}$ - Fageto-Piceetum humilis - 1.0\%, 8R - Piceetum turfosum (montanum) $-0.4 \%, 8 \mathrm{~K}-$ Piceetum acidophilum $-10.1 \%$. The terminology of the forest type groups is according to VIEWEGH et al. (2003).

B - Map of forest types in the catchments of Plešné Lake. The share of the individual forest type group in the PL catchment was: $7 \mathrm{~K}$ - Fageto-Piceetum acidophilum-1.2\%, $7 \mathrm{~N}$ - Fageto-Piceetum lapidosum acidophilum - 9.3\%, 7V - Fageto-Piceetum acerosum humidum $-0.5 \%, 7 \mathrm{Y}-$ Fageto-Piceetum saxatilis $-0.9 \%$, $8 \mathrm{~N}$ - Piceetum lapidosum acidophilum - 25.3\%, 8V - AceretoPiceetum humidum - $1.6 \%, 8 \mathrm{Y}$ - Acereto-Piceetum humidum $45.0 \%, 8 \mathrm{Z}$ - Sorbeto-Piceetum (humilis) - $16.2 \%$. The terminology of the forest type groups is according to VIEWEGH et al. (2003). 
Table 1. Mean abundance of plant species of the understory vegetation according to plant community classification groups, as determined by TWINSPAN. Species coverage is given in percents.

\begin{tabular}{|c|c|c|c|c|c|c|c|c|c|c|}
\hline Catchment & $\mathrm{CT}$ & $\mathrm{CT}$ & $\mathrm{CT}$ & $\mathrm{CT}$ & $\mathrm{CT}$ & PL & PL & PL & PL & $\mathrm{PL}$ \\
\hline TWINSPAN plant community classification groups & $* 000$ & $* 010$ & $* 011$ & $* 100$ & $* 101$ & $* 001$ & $* 100$ & *101 & $* 110$ & $* 111$ \\
\hline Number of relevés & 3 & 14 & 7 & 4 & 7 & 6 & 2 & 12 & 1 & 2 \\
\hline Representative area (ha) & 7.7 & 45.8 & 12.0 & 2.7 & 13.0 & 17.9 & 1.2 & 29.3 & 8.8 & 2.4 \\
\hline Athyrium distentifolium & 32 & & 0.1 & & & 27 & 2.5 & 0.8 & 10 & 35 \\
\hline Avenella flexuosa & & 16 & 6.5 & 16 & 3.4 & 4.2 & 20 & 1 & & \\
\hline Blechnum spicant & 0.5 & 0.5 & 1 & & 0.2 & & & & & \\
\hline Calamagrostis villosa & 38 & 57 & 37 & 15 & 1.2 & 13 & 7.5 & 0.8 & 1 & 28 \\
\hline Dryopteris dilatata & 5 & 3.1 & 2.2 & 1.5 & 1.1 & 10 & 1.5 & 1.7 & 2 & \\
\hline Epilobium angustifolium & & & & & & & & & & 1.5 \\
\hline Equisetum sylvaticum & 0.3 & & & & & & & & & \\
\hline Homogyne alpine & 0.7 & 0.1 & 0.1 & 0.1 & & 0.4 & & 0.1 & & \\
\hline Lastrea limbosperma & 10 & 0.4 & 0.1 & & & & & & & \\
\hline Luzula luzuloides & & & & & & 0.1 & & & & \\
\hline Luzula sylvatica & 6 & 2.8 & 1.7 & 0.1 & 0.1 & 11 & 0.5 & 0.3 & & \\
\hline Lycopodium annotinum & 0.3 & 0.5 & 0.1 & & 0.4 & & & & & \\
\hline Lycopodium clavatum & & & & & & & & 0.1 & & \\
\hline Maianthemum bifolium & & 0.1 & 0.3 & & 0.2 & 0.3 & & 0.1 & & \\
\hline Melampyrum sylvaticum & & 0.1 & 0.1 & 0.1 & 0.1 & & & & & \\
\hline Mycelis muralis & & & & & & & & 0.1 & & \\
\hline Oxalis acetosella & 1.7 & 0.6 & 0.5 & 0.3 & & 3.7 & 2 & 1.5 & & \\
\hline Phegopteris connectilis & 0.3 & & 0.1 & & & 0.7 & & & & \\
\hline Phegopteris dryopteris & 0.5 & & & & & & & & & \\
\hline Polygonatum multiflorum & & & & & & 0.1 & & & & \\
\hline Prenanthes purpurea & 0.5 & 0.1 & 0.6 & & 0.2 & 0.2 & & & & \\
\hline Rubus spp. Div. & 0.3 & & 0.1 & & & 0.5 & & 0.1 & 0.1 & 1 \\
\hline Senecio nemorensis & & & & 0.1 & & & & & & \\
\hline Silene vulgaris & & 0.1 & & & & & & & & \\
\hline Soldanella montana & & & & & & 0.2 & & & & \\
\hline Trientalis europaea & 0.2 & 0.1 & 0.2 & & & 0.1 & 0.5 & & & \\
\hline Vaccinium myrtillus & 1.3 & 1.1 & 27 & 58 & 75 & 17 & 52 & 82 & 72 & 20 \\
\hline Vaccinium vitis-idaea & & & & 0.1 & 0.4 & 0.2 & 2.5 & 2.6 & 5 & 2 \\
\hline
\end{tabular}

Explanations: CT - Čertovo Lake; PL - Plešné Lake; *000, *111, and *001 - plant communities dominated by A. distentifolium; *010, $* 011$, and $* 111$ - plant communities dominated by C. villosa; $* 100, * 101$, and $* 110$ - plant communities dominated by $V$. myrtillus).

1972 (MorAvec et al., 1982; MorAvec et al., 2000). The spatial distribution of individual vegetation groups within the CT and PL catchments (Fig. 2) was comparable with the forest types distribution (Fig. 1).

\section{Biomass of the understory vegetation}

A total of 40 and 50 biomass samples were analysed in the CT and PL catchments, respectively. The biomass of individual samples was highly variable. The mean biomass of $A$. flexuosa was 88 and $160 \mathrm{~g} \mathrm{~m}^{-2}$ in the CT and PL catchments, respectively, while it was 154 and $198 \mathrm{~g} \mathrm{~m}^{-2}$ for C. villosa (Tab. 2). The mean biomass of L. sylvatica was 278 and $226 \mathrm{~g} \mathrm{~m}^{-2}$ in the CT and PL catchments, respectively, while it was 561 and $713 \mathrm{~g}$ $\mathrm{m}^{-2}$ for $V$. myrtillus (Tab. 2). The estimated biomass of an average-sized $A$. distentifolium tussock $(1.4 \mathrm{~m}$ diameter) ranged from 187 to $205 \mathrm{~g}$ in the $\mathrm{CT}$ and $\mathrm{PL}$ catchments, respectively. Estimated AG biomass of A. distentifolium ranged from 191 to $234 \mathrm{~g} \mathrm{~m}^{-2}$. Mean AG biomass was estimated as $213 \mathrm{~g} \mathrm{~m}^{-2}$ in both catchments. The mean biomass of $C$. villosa and L. sylvatica was similar in the catchments, while those of $A$. distentifolium and $V$. myrtillus were relatively different.
Biomass allocation to the aboveground plant parts of V. myrtillus was as follows: leaves $-15 \%$ and $11 \%$, annual shoots $-38 \%$ and $47 \%$, and woody stems $-47 \%$ and $42 \%$ in the CT and PL catchments, respectively (Tab. 2).

The BG biomass of woody roots and rhizomes varied greatly among individual species and between the catchments (Tab. 3). Mean fine root biomass also differed among species and between catchments, but was not as variable as for woody roots and rhizomes (Tab. 3). It is likely that the BG fine root biomass values for individual species are within the same range in the $\mathrm{CT}$ and PL catchments.

The CWM AG biomass of the understory vegetation recorded in this study was 288 and $730 \mathrm{~g} \mathrm{~m}^{-2}$ in the CT and PL catchments, respectively (Tab. 4). The difference in the CWM AG biomass between the catchments was caused by the much higher abundance of $V$. myrtillus in the PL catchment. About $680 \mathrm{~g} \mathrm{~m}^{-2}$ of the CWM AG biomass in the PL catchment (730 g $\mathrm{m}^{-2}$ ) was represented by $V$. myrtillus. The woody stems of this evergreen dwarf shrub accounted for $41-47 \%$ of AG biomass in the PL catchment (Tab. 2). However, 
Table 2. Aboveground biomass according to the main types of microcoenoses.

\begin{tabular}{|c|c|c|c|c|c|c|c|}
\hline Locality & Type of microcoenose & $\mathrm{N}$ & $\begin{array}{l}\text { Mean biomass } \\
\qquad\left(\mathrm{g} \mathrm{m}^{-2}\right)\end{array}$ & $\begin{array}{l}\text { Carrying capacity } \\
\text { for dominant species } \\
\qquad\left(\mathrm{g} \mathrm{m}^{-2}\right)\end{array}$ & $\begin{array}{c}\text { Leaves } \\
(\%)\end{array}$ & $\begin{array}{c}\text { Annual shoots } \\
(\%)\end{array}$ & $\begin{array}{c}\text { Woody stems } \\
(\%)\end{array}$ \\
\hline $\mathrm{CT}$ & Avenella flexuosa & 5 & 88 & 95 & & & \\
\hline $\mathrm{CT}$ & Calamagrostis villosa & 23 & 154 & 219 & & & \\
\hline $\mathrm{CT}$ & Luzula sylvatica & 4 & 278 & 282 & & & \\
\hline $\mathrm{CT}$ & Vaccinium myrtillus & 12 & 561 & 924 & 15.0 & 37.7 & 47.3 \\
\hline PL & Avenella flexuosa & 4 & 160 & 178 & & & \\
\hline PL & Calamagrostis villosa & 6 & 198 & 222 & & & \\
\hline PL & Luzula sylvatica & 5 & 226 & 231 & & & \\
\hline PL & Vaccinium myrtillus & 20 & 713 & 1178 & 11.0 & 47.2 & 41.7 \\
\hline
\end{tabular}

Explanations: CT - Certovo Lake; PL - Plešné Lake; N - number of samples.

A

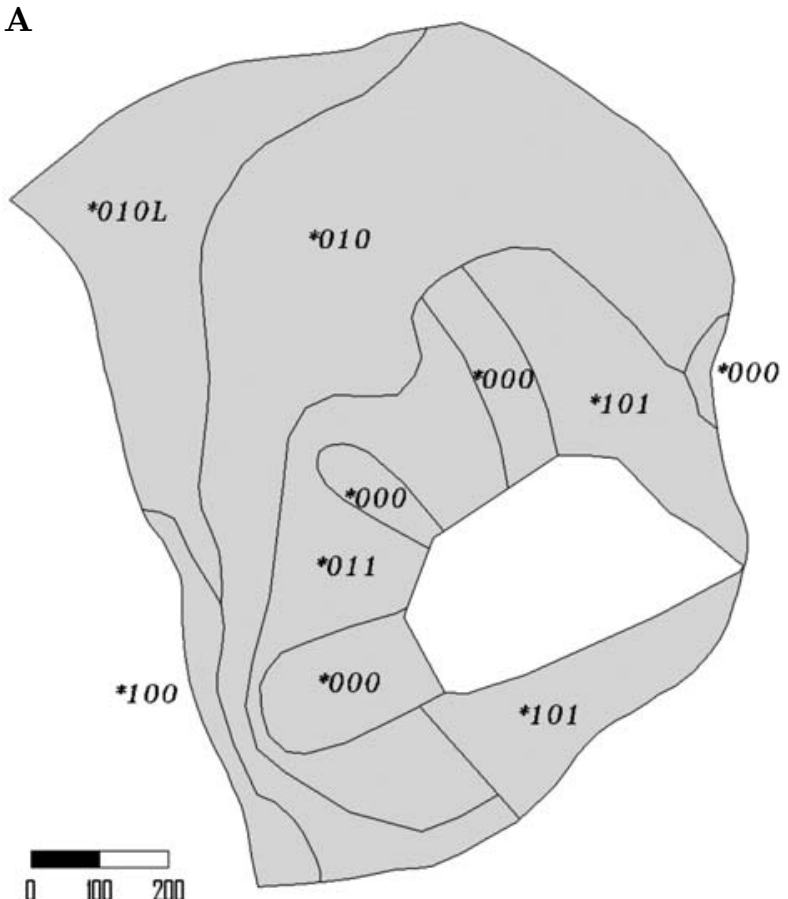

B

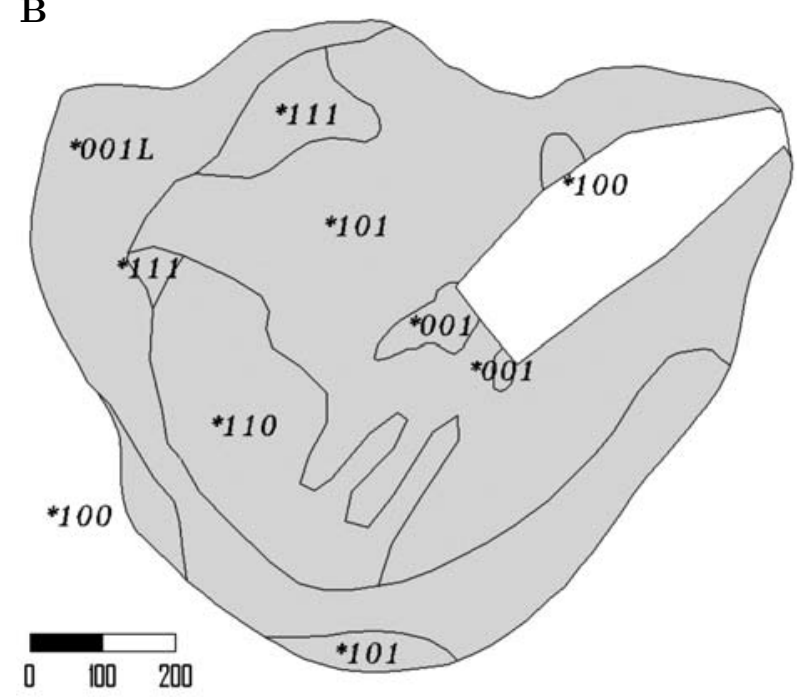

Fig. 2. Map of the plant communities according to TWINSPAN classification (Tab. 1) in the catchments of Certovo Lake (A) and Plešné Lake (b). For explanation of codes of plant communities see Table 1. the annually produced AG biomass was comparable for both catchments (142 and $124 \mathrm{~g} \mathrm{~m}^{-2}$ in the CT and PL catchments, respectively). The CWM BG fine root biomass recorded in this study was 491 and $483 \mathrm{~g} \mathrm{~m}^{-2}$ in the CT and PL catchments, respectively (Tab. 5). The CWM biomass of woody roots and rhizomes were not determined, because of high variability in the original data.

\section{Chemical elements in the biomass}

Mean element concentrations differed between the AG and BG biomass of the understory vegetation in both catchments (Tab. 6). There were differences also within and between the individual plant species in both catchments. However, the original data were highly variable, with only a relatively low number of samples. The CWM element pools in the AG biomass were 2-3fold higher in the PL than for the CT catchment, with the greatest differences observed for $\mathrm{Ca}, \mathrm{Na}$, and $\mathrm{Al}$ (Tab. 7). This difference reflected the higher CWM AG biomass of the understory vegetation in the PL catchment. The evergreen tissues of the dominant $V$. myrtillus in the PL catchment contained higher amounts of elements compared to the biomass of annual plant species that are dominant in the CT catchment. However, the recorded values were similar in both catchments when only element pools stored in annually produced AG biomass were compared (Tab. 7). The CWM element pools stored in the BG biomass of the $\mathrm{CT}$ and PL catchments were similar for most of the elements, except $\mathrm{Al}$ and $\mathrm{Fe}$. The higher $\mathrm{CWM} \mathrm{Al}$ and Fe pools in the CT catchment are probably related to the greater abundance of $C$. villosa and its higher concentrations of $\mathrm{Al}$ and $\mathrm{Fe}$.

\section{Discussion}

\section{Plant communities}

There were several possible explanations for the difference in the abundance of the dominant plant species of understory vegetation in the two catchments. The catchments differed in terms of species composition of the natural forest vegetation and soil types. This 
Table 3. Below-ground biomass (fine roots, woody roots and rhizomes) in selected sample plots representing the main types of microcoenoses. All values are in $\mathrm{g} \mathrm{m}^{-2}$.

\begin{tabular}{|c|c|c|c|c|c|}
\hline Catchment & Type of microcoenose & $\mathrm{N}$ & Fine roots & Woody roots & Rhizomes \\
\hline $\mathrm{CT}$ & Athyrium distentifolium & 6 & 669 & 28 & nd \\
\hline $\mathrm{CT}$ & Avenella flexuosa & 5 & 785 & 356 & 8 \\
\hline $\mathrm{CT}$ & Calamagrostis villosa & 23 & 567 & 59 & 190 \\
\hline $\mathrm{CT}$ & Luzula sylvatica & 4 & 321 & 666 & 137 \\
\hline $\mathrm{CT}$ & Vaccinium myrtillus & 12 & 730 & 212 & 1 \\
\hline PL & Athyrium distentifolium & 6 & 693 & 207 & 924 \\
\hline PL & Avenella flexuosa & 4 & 349 & 125 & 3 \\
\hline PL & Calamagrostis villosa & 6 & 391 & 481 & 113 \\
\hline $\mathrm{PL}$ & Luzula sylvatica & 5 & 376 & 199 & 18 \\
\hline PL & Vaccinium myrtillus & 20 & 616 & 461 & 95 \\
\hline
\end{tabular}

Explanations: CT - Čertovo Lake; PL - Plešné Lake; N - number of samples.

Table 4. Above-ground biomass of the understory vegetation according to plant communities for species A. flexuosa (Af), C. villosa (Cv), L. sylvatica (Ls), V. myrtillus (Vm) and A. distentifolium (Ad).

\begin{tabular}{|c|c|c|c|c|c|c|c|c|c|c|c|c|}
\hline \multirow[b]{2}{*}{ Plant community } & $\begin{array}{c}\text { Dominant species } \\
\text { carrying capacity }\left(\mathrm{g} \mathrm{m}^{-2}\right)\end{array}$ & $\begin{array}{c}\text { Af } \\
94.5\end{array}$ & $\begin{array}{c}\mathrm{Cv} \\
219.5\end{array}$ & $\begin{array}{c}\text { Ls } \\
282.1\end{array}$ & $\begin{array}{l}\mathrm{Vm} \\
923.7\end{array}$ & $\begin{array}{l}\text { Ad } \\
213\end{array}$ & Af & $\mathrm{Cv}$ & Ls & $\mathrm{Vm}$ & Ad & \multirow[t]{8}{*}{ Total } \\
\hline & Total area $\left(\mathrm{m}^{2}\right)$ & \multicolumn{5}{|c|}{ Species representation (\%) } & \multicolumn{5}{|c|}{ Average biomass $\left(\mathrm{g} \mathrm{m}^{-2}\right)$} & \\
\hline$* 000$ & 77000 & & 38 & 6 & 1 & 35 & & 83 & 16.9 & 9.2 & 74.6 & \\
\hline$* 010$ & 320570 & 16 & 57 & & 1 & & 15.1 & 125 & & 9.2 & & \\
\hline *010L & 137460 & 16 & 57 & 8 & 1 & & 15.1 & 125 & 22.6 & 9.2 & & \\
\hline$* 011$ & 120400 & 7 & 37 & 2 & 27 & & 6.6 & 81 & 5.6 & 249 & & \\
\hline$* 100$ & 26550 & 16 & 15 & & 58 & & 15.1 & 33 & & 536 & & \\
\hline *101 & 129980 & 4 & 1 & & 75 & & 3.8 & 2.2 & & 693 & & \\
\hline \multicolumn{2}{|c|}{ CWM AG biomass $\left(\mathrm{g} \mathrm{m}^{-2}\right)$} & & & & & & 10.6 & 92 & 6.3 & 172 & 7.1 & 287 \\
\hline \multicolumn{13}{|c|}{ B. Catchment of Plešné Lake. } \\
\hline & $\begin{array}{l}\text { Dominant species } \\
\text { carrying capacity }\left(\mathrm{g} \mathrm{m}^{-2}\right)\end{array}$ & $\begin{array}{c}\text { Af } \\
178.3\end{array}$ & $\begin{array}{c}\mathrm{Cv} \\
222.4\end{array}$ & $\begin{array}{c}\mathrm{Ls} \\
230.9\end{array}$ & $\begin{array}{c}\mathrm{Vm} \\
1177.0\end{array}$ & $\begin{array}{l}\text { Ad } \\
193\end{array}$ & Af & $\mathrm{Cv}$ & Ls & $\mathrm{Vm}$ & Ad & \multirow[t]{8}{*}{ Total } \\
\hline Plant community & Total area $\left(\mathrm{m}^{2}\right)$ & \multicolumn{5}{|c|}{ Species representation (\%) } & \multicolumn{5}{|c|}{ Average biomass $\left(\mathrm{g} \mathrm{m}^{-2}\right)$} & \\
\hline *001 & 8940 & 4 & 13 & & 17 & 27 & 7.1 & 28.9 & & 200 & 52.1 & \\
\hline$* 001 \mathrm{~L}$ & 170370 & 4 & 13 & 15 & 17 & 27 & 7.1 & 28.9 & 34.6 & 200 & 52.1 & \\
\hline *100 & 11890 & 20 & 8 & & 52 & 2 & 35.7 & 17.8 & & 612 & 3.9 & \\
\hline *101 & 292640 & 1 & 1 & & 82 & 1 & 1.8 & 2.2 & & 965 & 1.9 & \\
\hline$* 110$ & 87670 & & 1 & & 72 & 10 & & 2.2 & & 847 & 19.3 & \\
\hline$* 111$ & 24480 & & 28 & & 20 & 35 & & 62.3 & & 235 & 67.6 & \\
\hline \multicolumn{2}{|c|}{ CWM AG biomass $\left(\mathrm{g} \mathrm{m}^{-2}\right)$} & & & & & & 3.7 & 13 & 9.9 & 681 & 22.3 & 730 \\
\hline
\end{tabular}

was reflected by the phytosociological classification, where subassociation Calamagrostio villosae-Piceetum typicum Hartmann in Hartmann et Jahn, 1967 was dominant in the CT catchment (with dominant $C$. villosa), while subassociation Calamagrostio villosaePiceetum vaccinietosum myrtilli Jirásek, 1996 was dominant in the PL catchment (with dominant V. myrtillus). The soils of the CT catchment were mostly cambisols, while the PL catchment was dominated by undeveloped organic rich soils (KopÁČEK, 2002a, b). The latter soil type is often dominated by $V$. myrtillus.
The catchments also had different disturbance histories. Based on the phytosociological classification, a significant part of the forest stands of the CT catchment would be dominated by beech in the absence of human impact. However, the forest stands in this catchment were logged in the past and the species composition of the tree layer was probably changed, being now dominated by spruce (VESELÝ, 1994). The forest stands of the PL catchment are more or less naturally dominated by spruce. There is evidence that the coverage of grasses could increase, while that of dwarf shrubs would decrease, following man-made disturbance (UoTILA \& 
Table 5. Below-ground biomass of fine roots of the understory vegetation according to plant communities for the microcoenoses dominated by A. flexuosa (Af), C. villosa (Cv), L. sylvatica (Ls), V. myrtillus (Vm) and A. distentifolium (Ad) in the catchment of Certovo Lake.

A. Catchment of Certovo Lake.

\begin{tabular}{|c|c|c|c|c|c|c|c|c|c|c|c|c|}
\hline \multirow[b]{2}{*}{ Plant community } & $\begin{array}{c}\text { Dominant species } \\
\text { carrying capacity }\left(\mathrm{g} \mathrm{m}^{-2}\right)\end{array}$ & $\begin{array}{c}\text { Af } \\
785.2\end{array}$ & $\begin{array}{c}\mathrm{Cv} \\
567.3\end{array}$ & $\begin{array}{c}\text { Ls } \\
320.9\end{array}$ & $\begin{array}{l}\text { Vm } \\
730\end{array}$ & $\begin{array}{c}\text { Ad } \\
668.5\end{array}$ & Af & $\mathrm{Cv}$ & $\mathrm{Ls}$ & $\mathrm{Vm}$ & $\mathrm{Ad}$ & \multirow[t]{8}{*}{ Tota } \\
\hline & Total area $\left(\mathrm{m}^{2}\right)$ & \multicolumn{5}{|c|}{ Species representation (\%) } & \multicolumn{5}{|c|}{ Average biomass $\left(\mathrm{g} \mathrm{m}^{-2}\right)$} & \\
\hline *000 & 77000 & & 38 & 6 & 1 & 35 & & 216 & 19.2 & 7.3 & 234 & \\
\hline$* 010$ & 320570 & 16 & 57 & & 1 & & 126 & 323 & & 7.3 & & \\
\hline$* 010 \mathrm{~L}$ & 137460 & 16 & 57 & 8 & 1 & & 126 & 323 & 25.7 & 7.3 & & \\
\hline$* 011$ & 120400 & 7 & 37 & 2 & 27 & & 55 & 210 & 6.4 & 197 & & \\
\hline *100 & 26550 & 16 & 15 & & 58 & & 126 & 85 & & 423 & & \\
\hline *101 & 129980 & 4 & 1 & & 75 & & 31.4 & 5.7 & & 548 & & \\
\hline \multicolumn{7}{|c|}{ CWM BG biomass $\left(\mathrm{g} \mathrm{m}^{-2}\right)$} & 88.2 & 238 & 7.1 & 136 & 22.2 & 491 \\
\hline
\end{tabular}

B. Catchment of Plešné Lake.

\begin{tabular}{|c|c|c|c|c|c|c|c|c|c|c|c|c|}
\hline \multirow[b]{2}{*}{ Plant community } & $\begin{array}{c}\text { Dominant species } \\
\text { carrying capacity }\left(\mathrm{g} \mathrm{m}^{-2}\right)\end{array}$ & $\begin{array}{c}\text { Af } \\
348.7\end{array}$ & $\begin{array}{c}\mathrm{Cv} \\
390.9\end{array}$ & $\begin{array}{c}\mathrm{Ls} \\
375.6\end{array}$ & $\begin{array}{l}\mathrm{Vm} \\
616.4\end{array}$ & $\begin{array}{c}\text { Ad } \\
693.3\end{array}$ & Af & $\mathrm{Cv}$ & Ls & $\mathrm{Vm}$ & Ad & \multirow[t]{8}{*}{ Total } \\
\hline & Total area $\left(\mathrm{m}^{2}\right)$ & \multicolumn{5}{|c|}{ Species representation $(\%)$} & \multicolumn{5}{|c|}{ Average biomass $\left(\mathrm{g} \mathrm{m}^{-2}\right)$} & \\
\hline$* 001$ & 8940 & 4 & 13 & & 17 & 27 & 14 & 50.8 & & 105 & 187 & \\
\hline *001L & 170370 & 4 & 13 & 15 & 17 & 27 & 14 & 50.8 & 56.3 & 105 & 187 & \\
\hline$* 100$ & 11890 & 20 & 8 & & 52 & 2 & 69.7 & 31.3 & & 321 & 13.9 & \\
\hline *101 & 292640 & 1 & 1 & & 82 & 1 & 3.5 & 3.9 & & 506 & 6.9 & \\
\hline$* 110$ & 87670 & & 1 & & 72 & 10 & & 3.9 & & 444 & 69.3 & \\
\hline$*_{111}$ & 24480 & & 28 & & 20 & 35 & & 109 & & 123 & 243 & \\
\hline \multicolumn{2}{|c|}{ CWM BG biomass $\left(\mathrm{g} \mathrm{m}^{-2}\right)$} & & & & & & 7.3 & 22.9 & 16.1 & 357 & 80.2 & 483 \\
\hline
\end{tabular}

KoukI, 2005). The dense canopy of the beech stands results in often sparse understory vegetation, while the canopy of the spruce stands lets through more light, which enables the development of light demanding grass species such as C. villosa (HoLEKSA, 2003; WILD et al., 2004).

Acid deposition, resulting in soil acidification in the catchments of both lakes, was another important factor that could possibly affect species composition (KOPÁČEK, 2002c). There is some evidence that longterm soil acidification may cause changes in forest understory vegetation (KUBÍČEK et al., 1989; TONJE et al., 2004). Nitrogen deposition was shown to be the main factor affecting the vitality of dwarf shrubs not only in boreal forests of Fennoscandia (NORDIN et al., 1998; Strengbom et al., 2002, 2003, 2004). Their decline was followed by an increase in grass coverage induced by increased light availability. The fate of $\mathrm{N}$ differed between the PL and CT catchments, with the CT catchment being more saturated by $\mathrm{N}$ than the PL catchment. But, due to the dominant effect of light availability over $\mathrm{N}$ deposition on the composition of understory vegetation (STRENGBOM et al., 2004), the historical changes in forest structure and composition had probably a greater effect on the development of understory vegetation than $\mathrm{N}$ deposition in the catchments studied.

\section{Biomass}

The mean biomass of individual understory species is within the range found in the available literature. The mean AG biomass of C. villosa found in this study was 154 and $198 \mathrm{~g} \mathrm{~m}^{-2}$ in the CT and PL catchments, respectively. The values of the mean AG biomass for this species in Central Europe vary from 70 to 323 $\mathrm{g} \mathrm{m}^{-2}$ (FIEDLER \& HoHne, 1987; MATĚJKA, 1992a; PYŠEK, 1993; JAKRLOVÁ, 1996) in forest stands with closed canopy. In contrast, higher biomass was reported for this species (321-726 $\mathrm{g} \mathrm{m}^{-2}$ ) from areas with open canopy or on deforested sites (FIALA et al., 1989; JAKRLOVÁ, 1996). The mean BG biomass of C. villosa found in this study was 567 and $391 \mathrm{~g} \mathrm{~m}^{-2}$ in the CT and PL catchments, respectively. The mean BG biomass of this species reported by other studies was highly variable, from 48 to $3461 \mathrm{~g} \mathrm{~m}^{-2}$ (FIEDLER \& Hohne, 1987; Fiala et al., 1989; PYŠEK, 1993). The differences depended on whether the sampling was done in open or closed canopy forests, and the reported part of BG biomass (fine roots or rhizomes). The mean AG biomass of V. myrtillus found in this study (561 and $713 \mathrm{~g} \mathrm{~m}^{-2}$ in the CT and PL catchments, respectively) is at the low end of reported values for this species (100 and $3700 \mathrm{~g} \mathrm{~m}^{-2}$ ) (GERDOL et al., 2004). The relatively high mean biomass of $V$. myrtillus in the PL catchment is probably related to the more open canopy of 
Table 6a. Mean element concentrations in the biomass.

\begin{tabular}{|c|c|c|c|c|c|c|c|c|c|c|c|c|c|c|}
\hline Catchment & Species/category & $\begin{array}{c}\text { Type of } \\
\text { microcoenose }\end{array}$ & $\mathrm{N}$ & $\begin{array}{l}\text { Mean/ } \\
\text { SD }\end{array}$ & $\begin{array}{l}\mathrm{C} \\
\mathrm{mo}\end{array}$ & $\mathrm{kg}^{\mathrm{N}}$ & $\mathrm{P}$ & $\mathrm{Ca}$ & $\mathrm{Mg}$ & $\begin{array}{c}\mathrm{Na} \\
\mathrm{mmol}\end{array}$ & $\begin{array}{c}\mathrm{K} \\
\mathrm{kg}^{-1}\end{array}$ & $\mathrm{Al}$ & $\mathrm{Fe}$ & Mn \\
\hline \multirow[t]{5}{*}{$\mathrm{CT}$} & $\begin{array}{l}\text { Aboveground biomass } \\
\text { Athyrium distentifolium }\end{array}$ & Ad & 4 & $\begin{array}{l}\text { Mean } \\
\text { SD }\end{array}$ & $\begin{array}{l}40 \\
0.3\end{array}$ & $\begin{array}{l}2.1 \\
0.2\end{array}$ & $\begin{array}{l}81 \\
24\end{array}$ & $\begin{array}{l}83 \\
13\end{array}$ & $\begin{array}{l}107 \\
5.3\end{array}$ & $\begin{array}{l}0.5 \\
0.2\end{array}$ & $\begin{array}{c}920 \\
72\end{array}$ & $\begin{array}{l}3.2 \\
0.4\end{array}$ & $\begin{array}{l}1.6 \\
0.1\end{array}$ & $\begin{array}{l}9.4 \\
2.9\end{array}$ \\
\hline & Avenella flexuosa & Af & 4 & $\begin{array}{l}\text { Mean } \\
\text { SD }\end{array}$ & $\begin{array}{l}40 \\
0.3\end{array}$ & $\begin{array}{l}1.7 \\
0.1\end{array}$ & $\begin{array}{c}62 \\
2\end{array}$ & $\begin{array}{l}24 \\
2.7\end{array}$ & $\begin{array}{l}48 \\
1.5\end{array}$ & $\begin{array}{c}1 \\
0.2\end{array}$ & $\begin{array}{c}396 \\
44\end{array}$ & $\begin{array}{c}4.9 \\
2\end{array}$ & $\begin{array}{l}2.4 \\
0.3\end{array}$ & $\begin{array}{c}4 . \\
0.9\end{array}$ \\
\hline & Calamagrostis villosa & $\begin{array}{l}\mathrm{Ls} \\
\mathrm{Cv}\end{array}$ & $\begin{array}{l}1 \\
7\end{array}$ & $\begin{array}{l}\text { Mean } \\
\text { SD }\end{array}$ & $\begin{array}{l}41 \\
40 \\
0.7\end{array}$ & $\begin{array}{l}1.8 \\
1.6 \\
0.1\end{array}$ & $\begin{array}{l}78 \\
60 \\
6.8\end{array}$ & $\begin{array}{l}25 \\
27 \\
3.7\end{array}$ & $\begin{array}{c}25 \\
36 \\
4.7\end{array}$ & $\begin{array}{l}0.5 \\
0.5 \\
0.2\end{array}$ & $\begin{array}{c}461 \\
429 \\
44\end{array}$ & $\begin{array}{l}1.1 \\
2.2 \\
0.4\end{array}$ & $\begin{array}{l}1.2 \\
1.7 \\
0.1\end{array}$ & $\begin{array}{l}6.2 \\
5.4 \\
1.5\end{array}$ \\
\hline & Luzula sylvatica & Ls & 4 & $\begin{array}{l}\text { Mean } \\
\text { SD }\end{array}$ & $\begin{array}{l}39 \\
0.3\end{array}$ & $\begin{array}{l}1.5 \\
0.1\end{array}$ & $\begin{array}{l}84 \\
11\end{array}$ & $\begin{array}{l}28 \\
1.6\end{array}$ & $\begin{array}{l}77 \\
11\end{array}$ & $\begin{array}{l}1.5 \\
0.6\end{array}$ & $\begin{array}{c}559 \\
49\end{array}$ & $\begin{array}{l}5.1 \\
1.5\end{array}$ & $\begin{array}{c}2 \\
0.2\end{array}$ & $\begin{array}{c}6.4 \\
1\end{array}$ \\
\hline & $\begin{array}{l}\text { Vaccinium myrtillus - L } \\
\text { Vaccinium myrtillus - A } \\
\text { Vaccinium myrtillus - W }\end{array}$ & $\begin{array}{l}\mathrm{Vm} \\
\mathrm{Vm} \\
\mathrm{Vm}\end{array}$ & $\begin{array}{l}4 \\
4 \\
4\end{array}$ & $\begin{array}{l}\text { Mean } \\
\text { SD } \\
\text { Mean } \\
\text { SD } \\
\text { Mean } \\
\text { SD }\end{array}$ & $\begin{array}{c}42 \\
0.9 \\
43 \\
0.4 \\
42 \\
0.5\end{array}$ & $\begin{array}{l}1.5 \\
0.1 \\
0.8 \\
0.1 \\
0.5 \\
0.1\end{array}$ & $\begin{array}{l}49 \\
13 \\
27 \\
5.6 \\
14 \\
3.5\end{array}$ & $\begin{array}{c}157 \\
14 \\
127 \\
16 \\
55 \\
13\end{array}$ & $\begin{array}{c}81 \\
15 \\
35 \\
4.3 \\
14 \\
3\end{array}$ & $\begin{array}{c}0.6 \\
0.0 \\
1 \\
0.2 \\
0.4 \\
0.1\end{array}$ & $\begin{array}{c}234 \\
63 \\
88 \\
17 \\
38 \\
7.3\end{array}$ & $\begin{array}{l}6.9 \\
0.8 \\
5.9 \\
0.3 \\
6.3 \\
0.6\end{array}$ & $\begin{array}{l}1.8 \\
0.2 \\
1.6 \\
0.1 \\
1.7 \\
0.1\end{array}$ & $\begin{array}{c}14 \\
4.7 \\
18 \\
7.6 \\
11 \\
4.1\end{array}$ \\
\hline \multirow[t]{2}{*}{$\mathrm{CT}$} & $\begin{array}{l}\text { Below-ground biomass } \\
\text { Fine roots }\end{array}$ & $\begin{array}{c}\mathrm{Af} \\
\mathrm{Cv} \\
\mathrm{Ls} \\
\mathrm{Vm}\end{array}$ & $\begin{array}{l}3 \\
9 \\
2\end{array}$ & $\begin{array}{l}\text { Mean } \\
\text { SD } \\
\text { Mean } \\
\text { SD } \\
\text { Mean } \\
\text { SD } \\
\text { Mean } \\
\text { SD }\end{array}$ & $\begin{array}{c}43 \\
0.5 \\
43 \\
1.3 \\
42 \\
0.3 \\
44 \\
0.7 \\
43\end{array}$ & $\begin{array}{c}1 \\
0.1 \\
1 \\
0.1 \\
1 \\
0.0 \\
0.8 \\
0.1 \\
1.2\end{array}$ & $\begin{array}{c}26 \\
0.6 \\
28 \\
5 \\
31 \\
1.2 \\
22 \\
3 \\
29\end{array}$ & $\begin{array}{l}69 \\
15 \\
67 \\
23 \\
81 \\
6.2 \\
60 \\
13 \\
81\end{array}$ & $\begin{array}{c}29 \\
3.1 \\
27 \\
5.7 \\
33 \\
0.4 \\
23 \\
5.7 \\
58\end{array}$ & $\begin{array}{c}8.2 \\
1.6 \\
8 \\
3.5 \\
9.6 \\
2.3 \\
4.8 \\
2 \\
7\end{array}$ & $\begin{array}{c}34 \\
9.6 \\
31 \\
13 \\
27 \\
6.2 \\
26 \\
7.1 \\
24\end{array}$ & $\begin{array}{c}72 \\
11 \\
122 \\
87 \\
102 \\
21 \\
62 \\
24 \\
166\end{array}$ & $\begin{array}{c}21 \\
3.5 \\
32 \\
19 \\
41 \\
5 \\
18 \\
5.8 \\
34\end{array}$ & $\begin{array}{l}1.2 \\
0.1 \\
1.8 \\
0.6 \\
1.9 \\
0.2 \\
3.9 \\
2.8 \\
1.8\end{array}$ \\
\hline & Rhizomes & $\mathrm{Cv}$ & 4 & $\begin{array}{l}\text { Mean } \\
\text { SD }\end{array}$ & $\begin{array}{l}40 \\
0.6\end{array}$ & $\begin{array}{l}0.9 \\
0.1\end{array}$ & $\begin{array}{l}30 \\
11\end{array}$ & $\begin{array}{c}27 \\
4\end{array}$ & $\begin{array}{c}12.2 \\
2\end{array}$ & $\begin{array}{l}5.5 \\
1.5\end{array}$ & $\begin{array}{l}66 \\
27\end{array}$ & $\begin{array}{l}35 \\
15\end{array}$ & $\begin{array}{l}8.3 \\
2.5\end{array}$ & $\begin{array}{l}1.5 \\
0.5\end{array}$ \\
\hline
\end{tabular}

Explanations: N - number of samples; Mean - arithmetic mean; SD - standard deviation. Types of microcoenoses according to dominant species: Af - A. flexuosa; Cv - C. villosa; Ls - L. sylvatica; Vm - V. myrtillus; Ad - A. distentifolium. Aboveground categories for V. myrtillus: L - leaves; A - annual shoots; W - woody shoots. CT - Certovo Lake.

the forest stand; more light was available in the upper part of the catchment. Site conditions (soil type and tree canopy) were the main factors that influenced the biomass of this species. The mean AG biomass of A. flexuosa found in this study was 88 and $161 \mathrm{~g} \mathrm{~m}^{-2}$ in the CT and PL catchments, respectively, and was similar to values reported by MATĚJKA (1992a) (134$151 \mathrm{~g} \mathrm{~m}^{-2}$ ) and PaLviainen et al. (2005a) (40-90 g $\mathrm{m}^{-2}$ ). There is no simple explanation for the difference in mean biomass of $A$. flexuosa between the CT and PL catchments, because of the relatively low number of samples and their high variability. The recorded values of AG biomass (278 and $226 \mathrm{~g} \mathrm{~m}^{-2}$ ) of L. sylvatica were similar to ones reported by MATĚJKA (1992a) (192 g $\left.\mathrm{m}^{-2}\right)$. In spite of these data, there are not many studies dealing with the biomass of different understory vegetation species. However, it is still possible to conclude that forest canopy status (open or closed) and site conditions (soil type and fertility) are the main factors that can affect the biomass of the understory vegetation.

The CWM AG biomass for the herb species recorded in this study was 288 and $730 \mathrm{~g} \mathrm{~m}^{-2}$ in the CT and PL catchments, respectively. There are only a few studies that measured the biomass of the understory vegetation on the stand or catchment scales under similar site conditions. The recorded means for AG and BG biomass were 1290 and $516 \mathrm{~g} \mathrm{~m}^{-2}$, respectively in a spruce forest in Germany (SCARASCIA-MugNozzA et al., 2000). Even though the understory vegetation at this site was composed of similar species as in our sites (C. villosa, A. flexuosa, and V. myrtillus), the total biomass of the understory vegetation was higher. Much lower biomass values were reported from another spruce forest in Germany, where the recorded mean AG and BG values were 107 and $77-188 \mathrm{~g} \mathrm{~m}^{-2}$, respectively (Gerstberger et al., 2004). The understory vegetation at this German site was composed mostly of $C$. villosa. Similar AG and BG biomass values were reported from an old-growth spruce boreal forest in Finland. The understory vegetation at this site was composed mostly of $V$. myrtillus, which accounted for 150 and $300 \mathrm{~g} \mathrm{~m}^{-2}$ of AG and BG biomass, respectively (PAlviainen et al., 2005a). The characteristics of the tree stand, soil fertility, soil properties and climate have to be always considered when comparing the biomass of understory vegetation between sites. Understory vege- 
Table 6b. Mean element concentrations in the biomass.

\begin{tabular}{|c|c|c|c|c|c|c|c|c|c|c|c|c|c|c|}
\hline Catchment & Species/category & $\begin{array}{c}\text { Type of } \\
\text { microcoenose }\end{array}$ & $\mathrm{N}$ & $\begin{array}{l}\text { Mean/ } \\
\text { SD }\end{array}$ & $\begin{array}{l}\mathrm{C} \\
\mathrm{mol}\end{array}$ & $\underset{\mathrm{kg}^{-1}}{\mathrm{~N}}$ & $\mathrm{P}$ & $\mathrm{Ca}$ & $\mathrm{Mg}$ & $\begin{array}{c}\mathrm{Na} \\
\mathrm{nmol}\end{array}$ & $\underset{\mathrm{rg}^{-1}}{\mathrm{~K}}$ & $\mathrm{Al}$ & $\mathrm{Fe}$ & Mn \\
\hline \multirow[t]{5}{*}{ PL } & $\begin{array}{l}\text { Aboveground biomass } \\
\text { Athyrium distentifolium }\end{array}$ & Ad & 4 & $\begin{array}{l}\text { Mean } \\
\text { SD }\end{array}$ & $\begin{array}{l}41 \\
0.5\end{array}$ & $\begin{array}{l}2.1 \\
0.1\end{array}$ & $\begin{array}{c}136 \\
20\end{array}$ & $\begin{array}{l}71 \\
23\end{array}$ & $\begin{array}{c}75 \\
6\end{array}$ & $\begin{array}{l}0.7 \\
0.5\end{array}$ & $\begin{array}{l}817 \\
176\end{array}$ & $\begin{array}{l}4.1 \\
2.5\end{array}$ & $\begin{array}{l}1.8 \\
0.5\end{array}$ & $\begin{array}{c}6.1 \\
2\end{array}$ \\
\hline & Avenella flexuosa & Af & 4 & $\begin{array}{l}\text { Mean } \\
\text { SD }\end{array}$ & $\begin{array}{l}40 \\
0.2\end{array}$ & $\begin{array}{l}1.4 \\
0.1\end{array}$ & $\begin{array}{l}59 \\
5.9\end{array}$ & $\begin{array}{c}26 \\
3\end{array}$ & $\begin{array}{l}45 \\
6.7\end{array}$ & $\begin{array}{l}0.9 \\
0.0\end{array}$ & $\begin{array}{c}352 \\
70\end{array}$ & $\begin{array}{l}4.2 \\
0.4\end{array}$ & $\begin{array}{c}2 \\
0.1\end{array}$ & $\begin{array}{c}5.1 \\
1\end{array}$ \\
\hline & Calamagrostis villosa & $\begin{array}{l}\mathrm{Cv} \\
\mathrm{Ls}\end{array}$ & $\begin{array}{l}3 \\
1\end{array}$ & $\begin{array}{l}\text { Mean } \\
\text { SD }\end{array}$ & $\begin{array}{c}39 \\
0.2 \\
39\end{array}$ & $\begin{array}{l}1.6 \\
0.0 \\
1.4\end{array}$ & $\begin{array}{c}74.2 \\
7 \\
63.2\end{array}$ & $\begin{array}{c}33 \\
9 \\
18\end{array}$ & $\begin{array}{c}37 \\
1.6 \\
18\end{array}$ & $\begin{array}{l}0.4 \\
0.2 \\
1.2\end{array}$ & $\begin{array}{c}449 \\
85 \\
398\end{array}$ & $\begin{array}{l}1.9 \\
0.2 \\
1.1\end{array}$ & $\begin{array}{l}1.8 \\
0.1 \\
1.2\end{array}$ & $\begin{array}{l}7.1 \\
2.4 \\
1.9\end{array}$ \\
\hline & Luzula sylvatica & $\begin{array}{l}\mathrm{Cv} \\
\mathrm{Ls}\end{array}$ & $\begin{array}{l}1 \\
3\end{array}$ & $\begin{array}{l}\text { Mean } \\
\text { SD }\end{array}$ & $\begin{array}{l}40 \\
40 \\
0.1\end{array}$ & $\begin{array}{l}1.4 \\
1.4 \\
0.1\end{array}$ & $\begin{array}{l}60.1 \\
79.1 \\
15.6\end{array}$ & $\begin{array}{l}75 \\
54 \\
8.8\end{array}$ & $\begin{array}{l}87 \\
68 \\
5.9\end{array}$ & $\begin{array}{l}1.2 \\
2.2 \\
0.2\end{array}$ & $\begin{array}{c}974 \\
546 \\
92\end{array}$ & $\begin{array}{c}6 \\
12 \\
2.6\end{array}$ & $\begin{array}{l}1.5 \\
3.4 \\
0.5\end{array}$ & $\begin{array}{c}5.8 \\
6 \\
1.5\end{array}$ \\
\hline & $\begin{array}{l}\text { Vaccinium myrtillus - L } \\
\text { Vaccinium myrtillus - A } \\
\text { Vaccinium myrtillus - W }\end{array}$ & $\begin{array}{l}\mathrm{Vm} \\
\mathrm{Vm} \\
\mathrm{Vm}\end{array}$ & $\begin{array}{l}8 \\
8 \\
8\end{array}$ & $\begin{array}{l}\text { Mean } \\
\text { SD } \\
\text { Mean } \\
\text { SD } \\
\text { Mean } \\
\text { SD }\end{array}$ & $\begin{array}{c}42 \\
0.5 \\
43 \\
0.5 \\
43 \\
0.5\end{array}$ & $\begin{array}{l}1.5 \\
0.1 \\
0.8 \\
0.1 \\
0.5 \\
0.1\end{array}$ & $\begin{array}{c}54.6 \\
7.8 \\
29.2 \\
5.9 \\
15.7 \\
2.8\end{array}$ & $\begin{array}{c}176 \\
16 \\
137 \\
35 \\
64 \\
12\end{array}$ & $\begin{array}{c}84 \\
11 \\
40 \\
9.7 \\
18 \\
3.7\end{array}$ & $\begin{array}{l}0.5 \\
0.2 \\
1.2 \\
0.4 \\
0.6 \\
0.1\end{array}$ & $\begin{array}{c}255 \\
64 \\
102 \\
12 \\
47 \\
6.7\end{array}$ & $\begin{array}{l}6.5 \\
0.8 \\
7.1 \\
1.9 \\
6.9 \\
1.1\end{array}$ & $\begin{array}{l}1.6 \\
0.2 \\
1.4 \\
0.2 \\
1.7 \\
0.2\end{array}$ & $\begin{array}{c}9.8 \\
2.7 \\
12 \\
3 \\
9.1 \\
1.9\end{array}$ \\
\hline \multirow[t]{3}{*}{ PL } & $\begin{array}{l}\text { Below-ground biomass } \\
\text { fine roots }\end{array}$ & $\begin{array}{l}\text { Af } \\
\mathrm{Cv} \\
\mathrm{Ls} \\
\mathrm{Vm}\end{array}$ & $\begin{array}{l}2 \\
2 \\
2 \\
8\end{array}$ & $\begin{array}{l}\text { Mean } \\
\text { SD } \\
\text { Mean } \\
\text { SD } \\
\text { Mean } \\
\text { SD } \\
\text { Mean } \\
\text { SD }\end{array}$ & $\begin{array}{c}43 \\
0.7 \\
42 \\
1.0 \\
44 \\
0.3 \\
42 \\
0.6\end{array}$ & $\begin{array}{c}1 \\
0.0 \\
1 \\
0.0 \\
0.9 \\
0.1 \\
0.7 \\
0.2\end{array}$ & $\begin{array}{c}26.2 \\
1.7 \\
35.6 \\
7.4 \\
33.2 \\
2.4 \\
18.7 \\
3.6\end{array}$ & $\begin{array}{c}56 \\
8.2 \\
57 \\
12 \\
72 \\
4.8 \\
75 \\
24\end{array}$ & $\begin{array}{c}19 \\
1.5 \\
21.2 \\
3.6 \\
21 \\
0.9 \\
26 \\
7.7\end{array}$ & $\begin{array}{c}14.7 \\
8.6 \\
21 \\
2.2 \\
11 \\
3 \\
8 \\
5\end{array}$ & $\begin{array}{l}34 \\
15 \\
45 \\
3.9 \\
35 \\
12 \\
23 \\
5.1\end{array}$ & $\begin{array}{c}83 \\
60 \\
145 \\
37 \\
110 \\
28 \\
43 \\
24\end{array}$ & $\begin{array}{l}12 \\
3.3 \\
23 \\
6.5 \\
20 \\
3.1 \\
9.1 \\
3.6\end{array}$ & $\begin{array}{c}1 \\
0.2 \\
1.4 \\
0.2 \\
2.1 \\
0.3 \\
3.5 \\
1.7\end{array}$ \\
\hline & $\begin{array}{l}\text { Fine roots - in tussock } \\
\text { Fine roots - tussock fringe } \\
\text { Fine roots - between tussocks }\end{array}$ & $\begin{array}{l}\text { Ad } \\
\text { Ad } \\
\text { Ad }\end{array}$ & $\begin{array}{l}1 \\
1 \\
1\end{array}$ & & $\begin{array}{l}43 \\
42 \\
44\end{array}$ & $\begin{array}{l}1.3 \\
1.2 \\
1.3\end{array}$ & $\begin{array}{l}38.3 \\
34.1 \\
38.3\end{array}$ & $\begin{array}{l}86 \\
58 \\
71\end{array}$ & $\begin{array}{l}44 \\
26 \\
50\end{array}$ & $\begin{array}{l}35 \\
40 \\
10\end{array}$ & $\begin{array}{l}34 \\
57 \\
26\end{array}$ & $\begin{array}{l}159 \\
304 \\
135\end{array}$ & $\begin{array}{l}18 \\
36 \\
19\end{array}$ & $\begin{array}{l}1.2 \\
1.4 \\
0.8\end{array}$ \\
\hline & $\begin{array}{l}\text { Rhizomes - between tussocks } \\
\text { Rhizomes }\end{array}$ & $\begin{array}{c}\text { Ad } \\
\text { C }\end{array}$ & $\begin{array}{l}1 \\
1\end{array}$ & & $\begin{array}{l}43 \\
40\end{array}$ & $\begin{array}{l}1.4 \\
0.9\end{array}$ & $\begin{array}{l}42.2 \\
56.3\end{array}$ & $\begin{array}{l}92 \\
21\end{array}$ & $\begin{array}{l}63 \\
10\end{array}$ & $\begin{array}{l}7.3 \\
22\end{array}$ & $\begin{array}{l}98 \\
91\end{array}$ & $\begin{array}{l}19 \\
57\end{array}$ & $\begin{array}{l}1.9 \\
8.2\end{array}$ & $\begin{array}{l}0.6 \\
1.5\end{array}$ \\
\hline
\end{tabular}

Explanations: $\mathrm{N}$ - number of samples; Mean - arithmetic mean; SD - standard deviation. Types of microcoenoses according to dominant species: Af - A. flexuosa; Cv - C. villosa; Ls - L. sylvatica; Vm - V. myrtillus; Ad - A. distentifolium. Aboveground categories for $V$. myrtillus: L - leaves; A - annual shoots; W - woody shoots. PL - Plešné Lake.

tation is heterogeneous and can exhibit wide variability due to numerous factors (JALONEN et al., 1998). The biomass values recorded in this study correspond to the specific site and climate conditions of our study sites. The biomass was higher in the more productive German site, but lower in the less productive Finland site.

\section{Chemical elements in the biomass}

Element concentrations in sampled plant tissues differed both within and among species. This is in accordance with the general principles of plant mineral nutrition in that not all plant species require the same complement of minerals in the same amounts, but each species requires minerals in various proportions (CHAPIN \& AERTs, 2000). Despite the relatively low number of analysed samples, some differences were found in the element concentrations of plant tissues. For example, there was a clear difference in Al concentrations between the AG and BG biomass of all understory vegetation species. The increased concentrations of $\mathrm{Al}$ in the BG biomass could indicate increased availability of $\mathrm{Al}$ in soil solution due to soil acidification (KOPÁČEK, 2002a).

There are a limited number of generally accessible studies dealing with the nutrition of the plant species that we sampled, even though these are common species all over Europe. This relative lack of studies is likely due to the high spatial and seasonal variability in element concentrations in plant tissues (KAUNISTO \& SARJALA, 2003; GERDOL et al., 2004). The concentrations of P, $\mathrm{Ca}$, and $\mathrm{K}$ were 29,224 , and $196 \mathrm{mmol} \mathrm{kg}{ }^{-1}$, respectively, for $V$. myrtillus growing in a spruce boreal forest in Finland (PALVIAInEN et al., 2005b). The concentrations for $A$. flexuosa at the same site were 62,65 , and

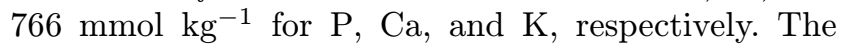
element concentrations for $V$. myrtillus in our study ranged from 13 to $55(\mathrm{P}), 55$ to $176(\mathrm{Ca})$, and 38 to $255(\mathrm{~K}) \mathrm{mmol} \mathrm{kg}{ }^{-1}$. These concentrations depended on 
Table 7. Mean pools of elements calculated per unit area within catchment.

\begin{tabular}{|c|c|c|c|c|c|c|c|c|c|c|c|c|c|}
\hline Catchment & $\begin{array}{l}\text { Dominant species/ } \\
\text { type of microcoenose }\end{array}$ & Category & $\begin{array}{l}\text { Biomass } \\
\mathrm{g} \mathrm{m}^{-2}\end{array}$ & $\begin{array}{c}\mathrm{C} \\
\mathrm{mol}\end{array}$ & $\begin{array}{r}\mathrm{N} \\
\mathrm{n}^{-2}\end{array}$ & $\mathrm{P}$ & $\mathrm{Ca}$ & $\mathrm{Mg}$ & $\begin{array}{l}\mathrm{Na} \\
\mathrm{mmol}\end{array}$ & $\begin{array}{c}\mathrm{K} \\
\mathrm{m}^{-2}\end{array}$ & $\mathrm{Al}$ & $\mathrm{Fe}$ & Mn \\
\hline \multirow[t]{9}{*}{$\mathrm{CT}$} & Avenella flexuosa & AG & 10.6 & 0.43 & 0.02 & 0.66 & 0.26 & 0.51 & 0.01 & 4.20 & 0.05 & 0.03 & 0.04 \\
\hline & Calamagrostis villosa & AG & 92.0 & 3.67 & 0.14 & 5.56 & 2.48 & 3.29 & 0.04 & 39.5 & 0.21 & 0.16 & 0.45 \\
\hline & Luzula sylvatica & $\mathrm{AG}$ & 6.3 & 0.25 & 0.01 & 0.53 & 0.18 & 0.49 & 0.01 & 3.52 & 0.03 & 0.01 & 0.04 \\
\hline & Vaccinium myrtillus & AG-L & 25.7 & 1.08 & 0.04 & 1.27 & 4.05 & 2.08 & 0.02 & 6.02 & 0.18 & 0.05 & 0.36 \\
\hline & $-"-$ & $\mathrm{AG}-\mathrm{A}$ & 64.7 & 2.76 & 0.05 & 1.72 & 8.20 & 2.29 & 0.06 & 5.71 & 0.38 & 0.09 & 1.17 \\
\hline & $-"-$ & AG-W & 81.1 & 3.44 & 0.04 & 1.12 & 4.50 & 1.15 & 0.03 & 3.07 & 0.51 & 0.14 & 0.90 \\
\hline & Athyrium distentifolium & AG & 7.1 & 0.28 & 0.02 & 0.64 & 0.59 & 0.76 & 0.01 & 6.53 & 0.02 & 0.01 & 0.07 \\
\hline & Annually produced AG biomass & & & 5.71 & 0.22 & 8.65 & 7.55 & 7.13 & 0.08 & 59.7 & 0.49 & 0.25 & 1.01 \\
\hline & Total AG biomass & & & 11.9 & 0.31 & 11.5 & 20.3 & 10.6 & 0.17 & 68.5 & 1.38 & 0.48 & 3.09 \\
\hline \multirow[t]{9}{*}{ PL } & Avenella flexuosa & AG & 3.7 & 0.15 & 0.01 & 0.22 & 0.09 & 0.17 & 0.01 & 1.30 & 0.02 & 0.01 & 0.02 \\
\hline & Calamagrostis villosa & AG & 13.0 & 0.50 & 0.02 & 0.96 & 0.43 & 0.48 & 0.01 & 5.84 & 0.03 & 0.02 & 0.09 \\
\hline & Luzula sylvatica & AG & 9.9 & 0.39 & 0.01 & 0.78 & 0.54 & 0.67 & 0.02 & 5.41 & 0.13 & 0.03 & 0.06 \\
\hline & Vaccinium myrtillus & AG-L & 74.9 & 3.15 & 0.11 & 4.09 & 13.2 & 6.29 & 0.04 & 19.1 & 0.49 & 0.12 & 0.73 \\
\hline & $-"-$ & $A G-A$ & 321.2 & 13.7 & 0.24 & 9.38 & 44.0 & 12.9 & 0.37 & 32.8 & 2.29 & 0.44 & 3.82 \\
\hline & $-"-$ & AG-W & 283.8 & 12.1 & 0.15 & 4.45 & 18.2 & 5.11 & 0.16 & 13.2 & 1.96 & 0.50 & 2.57 \\
\hline & Athyrium distentifolium & AG & 22.3 & 0.91 & 0.05 & 3.02 & 1.58 & 1.68 & 0.02 & 18.2 & 0.09 & 0.04 & 0.14 \\
\hline & Annually produced AG biomass & & & 5.11 & 0.20 & 9.08 & 15.8 & 9.29 & 0.08 & 49.8 & 0.74 & 0.22 & 1.04 \\
\hline & Total AG biomass & & & 30.9 & 0.59 & 22.9 & 78.0 & 27.3 & 0.61 & 95.9 & 4.98 & 1.16 & 7.43 \\
\hline \multirow[t]{6}{*}{$\mathrm{CT}$} & Avenella flexuosa & fine roots & 88.2 & 3.83 & 0.09 & 2.30 & 6.12 & 2.59 & 0.78 & 2.98 & 6.32 & 1.83 & 0.11 \\
\hline & Calamagrostis villosa & fine roots & 237.7 & 10.1 & 0.23 & 6.63 & 15.8 & 6.32 & 1.89 & 7.46 & 29.1 & 7.55 & 0.44 \\
\hline & Luzula sylvatica & fine roots & 7.1 & 0.30 & 0.01 & 0.22 & 0.57 & 0.24 & 0.07 & 0.19 & 0.72 & 0.29 & 0.01 \\
\hline & Vaccinium myrtillus & fine roots & 135.5 & 5.94 & 0.11 & 2.92 & 8.18 & 3.09 & 0.66 & 3.55 & 8.42 & 2.40 & 0.53 \\
\hline & Athyrium distentifolium & fine roots & 22.2 & 0.96 & 0.03 & 0.64 & 1.81 & 1.28 & 0.15 & 0.52 & 3.69 & 0.75 & 0.04 \\
\hline & Total BG biomass & & & 21.14 & 0.46 & 12.7 & 32.5 & 13.5 & 3.49 & 14.7 & 48.2 & 12.8 & 1.13 \\
\hline \multirow[t]{6}{*}{ PL } & Avenella flexuosa & fine roots & 7.3 & 0.31 & 0.01 & 0.19 & 0.41 & 0.14 & 0.11 & 0.24 & 0.61 & 0.09 & 0.01 \\
\hline & Calamagrostis villosa & fine roots & 22.9 & 0.97 & 0.02 & 0.82 & 1.30 & 0.49 & 0.49 & 1.02 & 3.33 & 0.53 & 0.03 \\
\hline & Luzula sylvatica & fine roots & 16.1 & 0.71 & 0.02 & 0.53 & 1.16 & 0.33 & 0.17 & 0.56 & 1.77 & 0.32 & 0.03 \\
\hline & Vaccinium myrtillus & fine roots & 356.5 & 15.0 & 0.26 & 6.67 & 26.8 & 9.07 & 2.84 & 8.06 & 15.3 & 3.27 & 1.24 \\
\hline & Athyrium distentifolium & fine roots & 80.2 & 3.44 & 0.10 & 2.96 & 5.74 & 3.19 & 2.28 & 3.11 & 16.0 & 1.95 & 0.09 \\
\hline & Total BG biomass & & & 20.5 & 0.41 & 11.2 & 35.4 & 13.2 & 5.89 & 13.0 & 36.9 & 6.15 & 1.40 \\
\hline
\end{tabular}

Explanations: Category: AG - above-ground biomass (AG-L - leaves, AG-A - annual shoots, AG-W - woody shoots; annual biomass contains total biomass all species except $V$. myrtillus of which only leaves and annual shoots are included). Biomass reports share of plant species on values of AG and BG CWB. CT - Čertovo Lake; PL - Plešné Lake.

the type of biomass sampled (leaves, annual shoots, and woody stems) (Tab. 6). For A. flexuosa, the P, Ca, and $\mathrm{K}$ concentrations ranged from 59 to 62,24 to 26 , and 352 to $396 \mathrm{mmol} \mathrm{kg}{ }^{-1}$, respectively. $\mathrm{N}$ and $\mathrm{P}$ concentrations were $0.3 \mathrm{~mol} \mathrm{~kg}{ }^{-1}$ and $29 \mathrm{mmol} \mathrm{kg}{ }^{-1}$, respectively, in $V$. myrtillus from a sub-alpine forest in Italy (GERDol et al., 2004). The element concentrations of V. myrtillus in our study ranged from 14 to $55 \mathrm{mmol}$ $\mathrm{kg}^{-1}$ and from 0.7 to $1.5 \mathrm{~mol} \mathrm{~kg} \mathrm{~kg}^{-1}$ for $\mathrm{P}$ and $\mathrm{N}$, respectively. Given the fact that these three sites differ in their site conditions and the analytical methods used, these values are reasonably comparable.

The CWM element pools differed between the CT and PL catchments. The total amount of elements stored in the PL catchment understory vegetation was considerably higher, because of the higher CWM biomass of its understory vegetation. But the el- ement pools were similar when only annually produced AG biomass was compared. PALviAinen et al. (2005b) showed that total element pools in understory vegetation biomass $\left(504 \mathrm{~g} \mathrm{~m}^{-2}\right)$ was $0.34 \mathrm{~mol} \mathrm{~m}^{-2}(\mathrm{~N})$, $13 \mathrm{mmol} \mathrm{m}^{-2}(\mathrm{P}), 41 \mathrm{mmol} \mathrm{m}^{-2}(\mathrm{~K})$, and $35 \mathrm{mmol}$ $\mathrm{m}^{-2}(\mathrm{Ca})$ in the boreal spruce forest. The total CWM biomass of the understory vegetation was 288 and 730 $\mathrm{g} \mathrm{m}^{-2}$, with element pools of 0.3 and $0.6 \mathrm{~mol} \mathrm{~m}^{-2}(\mathrm{~N})$, 12 and $23 \mathrm{mmol} \mathrm{m}^{-2}(\mathrm{P}), 69$ and $96 \mathrm{mmol} \mathrm{m}^{-2}(\mathrm{~K})$, and 20 and $78 \mathrm{mmol} \mathrm{m}^{-2}(\mathrm{Ca})$ in the PL and CT catchments, respectively. These reported element pools are within the range found in the boreal forest.

\section{Conclusions}

We observed important differences in the character, composition, and biomass of understory vegetation be- 
tween the PL and CT catchments in the Bohemian Forest, resulting in significant differences in the associated pools of key elements. The CWM AG biomass of the understory vegetation, as well as the associated CWM elements pools, was 2-3 times higher in the PL than CT catchment, with the greatest differences observed for $\mathrm{Ca}, \mathrm{Na}$, and $\mathrm{Al}$. The differences were predominantly caused by higher abundance of $V$. myrtillus in the PL catchment, while the understory vegetation was dominated by $C$. villosa in the CT catchment. The CWM $\mathrm{BG}$ biomass of the understory vegetation was similar in both catchments.

The differences in both site factors and history of land use were probably responsible for the observed differences in the character and pools of the understory vegetation in the CT and PL catchments. The catchments differ in the proportion of individual soil types and catchments morphology. Without a more detailed knowledge of the land use history and its impact on the vegetation in the catchments, it is, however, difficult to conclude whether the difference in the character of understory vegetation reflects the natural or anthropogenic factors.

The major aim of this study was to evaluate differences in the understory vegetation in the $\mathrm{PL}$ and CT catchments. Further evaluation of the data (SvOBODA et al., 2006; ŠANTRŮČKOVÁ et al., 2006), however, suggested their following implication for whole ecosystems studies: (1) The understory vegetation of C. villosa played an important role in $\mathrm{N}$ balance on the catchment scale. The higher abundance of $C$. villosa in the CT catchment possibly caused higher $\mathrm{N}$ flux from the litter to the CT soil compared to the PL catchment, where $V$. myrtillus was the most abundant species (ŠAnTRŮČKOvÁ et al., 2006). (2) Comparing the data on element pools in understory vegetation to those in the tree layer showed that the annual uptake of nutrients by these two vegetation layers were of the same magnitude (SvobodA et al., 2006). These results imply that adequate attention should be paid to the role of understory vegetation in element cycling at the whole ecosystem scale.

\section{Acknowledgements}

We acknowledge the field and laboratory assistance provided by our colleagues from the Faculty of Environment, Czech University of Agriculture in Prague (particulary to K. Grygarová, M. Č́İ̌zeK, B. Pitnerová, L. HatlaPATKOVÁ, and R. Śloc). We thank the Sumava National Park authorities for their administrative support. We thank K. EDWARDS for proof reading. This study was supported by the Grant Agency of the Czech Republic (project No. 206/03/1583) and partly by the Grant Agency of the Ministry of Agriculture of the Czech Republic (project No. NAZV QG50105).

\section{References}

Chapin, F.S. \& Aerts, R. 2000. The mineral nutrition of wild plants revisited: A re-evaluation of processes and patterns. Adv. Ecol. Res. 30: 1-67.

Fiala, K., JakrlovÁ, J. \& ZelenÁ, V. 1989. Biomass partitioning in two Calamagrostis villosa stands on deforested sites. Folia Geobot. 24: 207-210.

Fiala, K., Tưma, I., Holub, P. \& JandÁk, J. 2005. The role of Calamagrostis communities in preventing soil acifitication and base cation losses in a deforested mountain area affected by acid deposition. Plant Soil 268: 35-49.

Fiedler, H.J. \& Hohne, H. 1987. Biomass production and nutrient content of Calamagrostis villosa (Chaix) J. F. Gmelin in a spruce forest. Flora 179: 109-123.

Finer, L., Mannerkoski, H., Piirainen, S. \& Starr, M. 2003. Carbon and nitrogen pools in an old-growth, Norway spruce mixed forest in eastern Finland and changes associated with clear-cutting. For. Ecol. Manag. 174: 51-63.

George, L.O. \& Bazzaz, F.A. 1999. The fern understory as an ecological filter: emergence and establishment of canopy-tree seedlings. Ecology 80: 833-845.

Gerdol, R., Anfodillo, T., Gualmini, M., Cannone, N., Luca, B. \& Brancaleoni, L. 2004. Biomass distribution of two subalpine dwarf-shrubs in relation to soil moisture and nutrient content. J. Veg. Sci. 15: 457-464.

Gerstberger, P., Foken, T. \& Kalbitz, K. 2004. The Lehstenbach and Steinkreuz catchments in NE Bavaria, Germany, pp. 15-41. In: MATZnER, E. (ed.) Biogeochemistry of forested catchments in a changing environment, Ecological Studies 172, Springer-Verlag, Berlin - Heidelberg.

HelmisAari, H.S. 1995. Nutrient cycling in Pinus sylvestris stands in eastern Finland. Plant Soil 168-169: 327-336.

HILL, M.O. 1979. TWINSPAN - a FORTRAN program for arranging multivariate data in an ordered two way table by classification of individuals and attributes. Cornell Univ., Ithaca, 48 pp.

HoleKSA, J. 2003. Relationship between field-layer vegetation and canopy openings in a Carpathian subalpine spruce forest. Plant Ecol. 168: 57-67.

Holub, P. 1999. Hodnocení příjmu dusíku a jeho retranslokace travami na odlesněných plochách [Assessment of nitrogen uptake and its retranslocation by gramineous plants on the deforested land]. J. For. Sci. 45: 358-364.

Huber, C., Weis, W., Buamgarten, M. \& Gottlein, A. 2004. Spatial and temporal variation of seepage water chemistry after femel and small scale clear-cutting in a N-saturated Norway spruce stand. Plant Soil 267: 23-40.

Husová, M., Jirásek, J. \& Moravec, J. 2002. Jehličnaté lesy [Coniferous forests]. In: Moravec, J. (ed.) Přehled vegetace České republiky [Vegetation survey of the Czech Republic], Vol. 3, Academia, Praha, 128 pp.

JAKRLOVÁ, J. 1996. Variability of aboveground production of Calamagrostis villosa in localities exposed to immissions in the region of Beskydy Mts, pp. 75-82. In: FiALA, K. (ed.) Grass ecosystems of deforested areas in the Beskydy Mts, Preliminary results of ecological studies, Proceedings of the workshop held in Brno, Institute of Landscape Ecology, Brno.

JANkOVSKÁ, V. 2006. Late Glacial and Holocene history of Plešné Lake and its surrounding landscape based on pollen and palaeoalgological analyses. Biologia, Bratislava 61, Suppl. 20: S371-S385.

Jalonen, J., VAnha-MajamaA, I. \& Tonteri, T. 1998. Optimal sample and plot size for inventory of field and ground layer vegetation in a mature Myrtillus-type boreal spruce forest. Ann. Bot. Fenn. 35: 191-196.

JiRÁSEK, J. 1996. Přirozené smrčiny České republiky [Natural spruce forest of the Czech republic]. Preslia 67: 225-259.

JonAsson, S. \& Shaver, G.R. 1999. Within-stand nutrient cycling in arctic and boreal wetlands. Ecology 80: 2139-2150.

KAŇA, J. \& KOPÁČEK, J. 2006. Impact of soil sorption characteristics and bedrock composition on phosphorus concentrations 
in two Bohemian Forest lakes. Water Air Soil Pollut. 173: $243-259$.

Kaunisto, S. \& SARJala, T. 2003. Foliar pottassium concentrations of Bilberry, Bog Bilberry and Downy Birch as indicator of Potassium nutrition of Scots pine on a drained peatland. Silva Fenn. 37: 235-332.

Kopáček, J., Borovec, J., Hejzlar, J. \& Porcal, P 2001. Parallel spectrophotometric determinations of iron, aluminum, and phosphorus in soil and sediment extracts. Comm. Soil Sci. Plant. 32: 1431-1443.

Kopácek, J., Kaña, J., ŠantrưČková, H., Porcal, P., Hejzlar, J., Picek, T., Šimek, M. \& Veselý, J. 2002a. Physical, chemical and biological characteristics of soils in watersheds of the Bohemian Forest lakes: I. Plešné Lake. Silva Gabreta 8: 43-66.

Kopácek, J., Kaña, J., ŠantrưČková, H., Porcal, P., HejZlar, J., Picek, T., Šimek, M. \& Veselý, J. 2002b. Physical, chemical and biological characteristics of soils in watersheds of the Bohemian Forest lakes: II. Čertovo and Černé Lakes. Silva Gabreta 8: 97-94.

KopÁČek, J., Stuchlík, E., Veselý, J., Schaumburg, J., ANDerson, I.C., Fott, J., Hejzlar J. \& Vrba J. 2002c. Hysteresis in reversal of Central European mountain lakes from atmospheric acidification. Water Air Soil Pollut.: Focus 2: 91-114.

Kopácek, J. Turek, J., Hejzlar, J., Kaña, J. \& Porcal, P. 2006a. Element fluxes in watershed-lake ecosystems recovering from acidification: Certovo Lake, the Bohemian Forest, 2001-2005. Biologia, Bratislava 61, Suppl. 20: S413-S426.

Kopácé, J., Turek, J., Hejzlar, J., Kaña, J. \& Porcal, P. 2006b. Element fluxes in watershed-lake ecosystems recovering from acidification: Plešné Lake, the Bohemian Forest, 2001-2005. Biologia, Bratislava 61, Suppl. 20: S427-S440.

Kubát, K., Hrouda, L., Chrtek, J., Kaplan, Z., Kirchner, J. \& ŠTĚPÁneK J. (eds) 2002. Klíč ke květeně České republiky [Key to the Flora of the Czech Republic]. Academia, Praha, $928 \mathrm{pp}$.

Kubíček, F., Simonovič, V. \& Szabo, J. 1989. Biomass of the herb layer and moss layer in several forest ecosystems influenced by air pollution, the Beskydy mountains (part Kysuce). Ekológia (CSSR) 8: 23-34.

Majer, V., Cosby, B.J., Kopá̌é, J. \& VeselÝ, J. 2003. Modeling reversibility of Central European mountain lakes from acidification: Part I - The Bohemian Forest. Hydrol. Earth Syst. Sci. 7: 494-509.

MATÉJKA, K. 1992a. A case study of mountain spruce forest problems and comments, pp. 42-50. In: MATẼJKA, K. (ed.) Investigation of the mountain forest ecosystems and of forest damage in the Czech Republic, Proceedings of the workshop held in České Budějovice, České Budějovice.

MATĚJKA, K. 1992b. Some aspects of the theory of the ecosystem spatial structure. I. Theory. Ekológia (ČSFR) 11: 369-377.

Moravec, J. et al. 1994. Fytocenologie. Academia, Praha, 403 pp.

Moravec, J., Husová, M., Chytrý, M. \& Neuhäuslová, Z. 2000. Hygrofilní, mezofilní a xerofilní opadavé lesy [Hygrophilous, mesophilous and xerophilous deciduous forests]. In: Moravec, J. (ed.) Přehled vegetace Ceské republiky [Vegetation survey of the Czech Republic], Vol. 2, Academia, Praha, 319 pp.

Moravec, J., Husová, M., Neuhäusl, R. \& NeuhäuslováNovotnA, Z. 1982. Die Association mesophiler und hygrophiler Laubwälder in der Tschechischen Sozialistischen Republik. Vegetace ČSSR, Ser. A, Vol. 12. Academia, Praha, 296 pp.

NiLSSON, M.C. \& WARDLE, D.A. 2005. Understory vegetation as a forest ecosystem driver: evidence from the northern Swedish boreal forest. Front. Ecol. Environ. 8: 421-428.
Nordin, A., NASholm, T. \& ERICson, L. 1998. Effects of simulated $\mathrm{N}$ deposition on understorey vegetation of a boreal coniferous forest. Funct. Ecol. 12: 691-699.

Odum, E.P. 1959. Fundamentals of ecology. $2^{\text {nd }}$ Ed. Saunders, Philadelphia, 546 pp.

Pavliainen, M., Finér, L. \& Mannerkoski, H. 2005a. Response of ground vegetation species to clear-cutting in a boreal forest: aboveground biomass and nutrient contents during the first 7 years. Ecol. Res. 20: 652-660.

Pavliainen, M., Finér, L., Mannerkoski, H., Piirainen, S. \& Starr., M. 2005b. Changes in the above- and belowground biomass and nutrient pools of ground vegetation after clear-cutting of a mixed boreal forest. Plant Soil 275: 157167.

PYŠEK, P. 1993. What do we know about Calamagrostis villosa? A review of the species behaviour in secondary habitats. Preslia 65: $1-20$.

Rodenkirchen, H. 1995. Nutrient pools and fluxes of the ground vegetation in coniferous forests due to fertilizing, liming and amelioration. Plant Soil 168-169: 383-390.

Scarascia-Mugnozza, G., Bauer, G.A. Persson, H., MatTEUCCI, G. \& MASCI, A. 2000. Tree biomass, growth, and nutrient pools, pp. 49-61. In: Schulze, E.D. (ed.) Carbon and nitrogen cycling in European forest ecosystems, Ecological Studies 142, Springer-Verlag, Berlin-Heidelberg.

Strengbom, J., Nordin, A., Nasholm, T. \& Ericson, L. 2002. Parasitic fungus mediates change in nitrogen-exposed boreal forest vegetation. J Ecol. 90: 61-67.

Strengbom, J., Walheim, M., Nasholm, T. \& Ericson, L. 2003. Regional differences in the occurrence of understorey species reflect nitrogen deposition in Swedish forests. Ambio 32: $1-97$.

Strengbom, J., Nasholm, T. \& Ericson, L. 2004. Light, not nitrogen, limits growth of the grass Deschampsia flexulosa in boreal forests. Can. J. Bot. 82: 430-435.

Svoboda, M., MatěJKa, K., KopÁČek, J. \& Žaloudík, J. 2006. Estimation of tree biomass of Norway spruce forest in the Plešné Lake catchment, the Bohemian Forest. Biologia, Bratislava 61, Suppl. 20: S523-S532.

ŠantrúČKová, H., KrištúfKova, M. \& VAnĚK, D. 2006. Decomposition rate and nutrient release from plant litter of Norway spruce forest in the Bohemian Forest. Biologia, Bratislava 61, Suppl. 20: S499-S508.

Tonje, O., Bakkestuen, V., Halvorsen, O.R. \& Odd, E. 2004. Changes in forest understorey vegetation in Norway related to long-term soil acidification and climatic change. J. Veg. Sci. 15: 437-448.

Uotila, A. \& Kouki, J. 2005. Understorey vegetation in sprucedominated forests in eastern Finland and Russian Karelia: Successional patterns after anthropogenic and natural disturbances. For. Ecol. Manag. 215: 113-137.

VESELY, J. 1994. Investigation of the nature of the Sumava lakes: a review. Čas. Nár. Muz. Praha, Řada Přírodověd. 163: 103120.

Viewegh, J., Kusbach, A. \& Mikeska, M. 2003. Czech forest ecosystem classification. J. For. Sci. 49: 74-82.

Vrba, J., KopáČek, J., Fott, J., Kohout, L., Nedbalová, L., Pražáková, M., Soldán, T. \& Schaumburg. J. 2003. Long-term studies (1871-2000) on acidification and recovery of lakes in the Bohemian Forest (Central Europe). Sci. Total Environ. 310: 73-85.

Wild, J., Neuhauslova, Z. \& Sofron, J. 2004. Changes of plant species composition in the Sumava spruce forests, SW Bohemia, since the 1970s. For. Ecol. Manag. 187: 117-132.

Received May 29, 2006 Accepted November 15, 2006 